\title{
Multiproxy reconstruction for Kuroshio responses to northern hemispheric oceanic climate and the Asian Monsoon since Marine Isotope Stage 5.1 ( 88 ka)
}

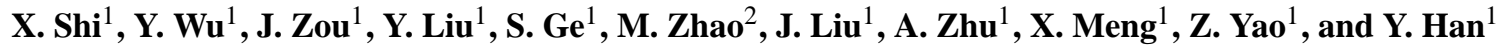 \\ ${ }^{1}$ Key Laboratory of Marine Sedimentology and Environmental Geology, First Institute of Oceanography, State Oceanic \\ Administration, Qingdao 266061, China \\ ${ }^{2}$ Key Laboratory of Marine Chemistry Theory and Technology (Ocean University of China), Ministry of Education/Qingdao \\ Collaborative Innovation Center of Marine Science and Technology, Qingdao 266100, China
}

Correspondence to: X. Shi (xfshi@fio.org.cn)

Received: 26 February 2014 - Published in Clim. Past Discuss.: 4 April 2014

Revised: 7 August 2014 - Accepted: 19 August 2014 - Published: 18 September 2014

\begin{abstract}
The Kuroshio, a western boundary current in the northwestern Pacific, plays a key role in regulating ocean and climate in East Asia. The evolution of the Kuroshio and its branches has been the focus of paleoceanographic studies. In this study, we applied a multiproxy (grain size, planktonic foraminiferal species, $\delta^{18} \mathrm{O}$, alkenone sea surface temperature (SST) and salinity) reconstruction from sediment core CSH1, which is located at the main axis of the Tsushima Warm Current, a branch of the Kuroshio, in the northern Okinawa Trough (OT). This study, extended the paleoceanographic record of the Kuroshio to Marine Isotope Stage (MIS) $5.1(\sim 88 \mathrm{ka})$ from the far northern site in the OT. Planktonic foraminiferal species identified from this core contain warm-water species related to the Kuroshio and coldwater species related to subarctic water mass. The relative abundances of the warm-water species are high during MIS 1 and MIS 5.1, while cold-water species are high during MIS 2. An organic biomarker proxy, alkenone SST measured from core CSH1 ranges between 21 and $25^{\circ} \mathrm{C}$, with higher values during interglacials (MIS 1, 3.3, 5.1) and interstadials and lower values during glacials and Heinrich $(\mathrm{H}) /$ stadial events. Sea surface salinity (SSS) and the depth of the thermocline (DOT), reconstructed based on foraminifera isotopes and faunas, indicate dominant Kuroshio responses to an abrupt climate change event recorded in Greenland ice cores and in stalagmites in East China since $\sim 88 \mathrm{ka}$. The CSH1 SSS appears to be mainly controlled by the local river runoff and the Kuroshio, while the DOT change seems to be closely re-
\end{abstract}

lated to the strength of the Kuroshio and the latitudinal shift of the subarctic frontal zone. Our records suggest that, during MIS 1 and MIS 5.1, while global sea level was high, the Kuroshio was dominant; while during MIS 2, MIS 3 and MIS 4, with a low sea level, stronger winter Asian Monsoon (AM) and a more southerly subarctic front played important roles in governing the hydrographic characteristics in the OT. Spectral analysis of our multiproxy hydrographic records shows a dominant precessional period at $\sim 24 \mathrm{ka}$. Our hydrographic records, such as SST, SSS and DOT, from a site near the modern Tsushima Warm Current show regional responses corresponding mainly to the global sea level, the Kuroshio, AM and subarctic front, factors which are consistently invoked in the interpretations of other regional records from the OT.

\section{Introduction}

The meridional heat transport by ocean currents, such as the Gulf Stream in the North Atlantic and the Kuroshio in the North Pacific, plays a critical role in setting the global energy balance and regulating climate change. The Kuroshio carries large amounts of heat, salt and moisture from low latitudes; it enters the Okinawa Trough (OT) with a high current velocity, great volume transport and a narrow width and extends to the far northwestern Pacific. It exerts great influence on the climate and environmental conditions of East 
Asia (Hsueh, 2000; Hsueh et al., 1992). In the northern OT, two branches of the Kuroshio, the Tsushima Warm Current (TWC) and the Yellow Sea Warm Current, enter into the Sea of Japan through the shallow Tsushima Strait, with a sill depth of $130 \mathrm{~m}$, and into the Yellow Sea, respectively, while the main stream of the Kuroshio continues to flow northwardly along the east coast of Japan and turns across the northwestern Pacific at $\sim 38^{\circ} \mathrm{N}$. Besides the Kuroshio, the climate of the western Pacific is also regulated by the Asian Monsoon (AM). The freshwater discharged by the Yangtze and Yellow Rivers directly influences the surface water salinity and the primary productivity and, therefore, the organic carbon export and burial in the adjoining continental margins. Since OT is located adjacent to the wide shelf of the East China Sea (ECS), abundant high-resolution information on past climate and oceanographic changes could be extracted from marine sediment cores from the OT because of the very high sedimentation rate in the OT.

Previous studies on past climate changes using sediment cores from the OT show orbital-scale (Ijiri et al., 2005; Kao et al., 2006a; Kawahata et al., 2006; Zhou et al., 2007), millennial and abrupt climatic responses, such as the 8.2 ka event, the Younger Dryas, Heinrich $(\mathrm{H})$ events and the DansgaardOeschger cycles of the Kuroshio (Chang et al., 2008, 2009; Ijiri et al., 2005; Li et al., 2001; Liu et al., 2001; Yu et al., 2009). However, most of these studies were limited by either shorter cores or single-proxy reconstruction (Jian et al., 1998; Kao et al., 2006b; Lee et al., 2013; Ujiié and Ujiié, 1999) that covered only a small spatial scale of the OT which the Kuroshio has entered. In this study, we present a multiproxy reconstruction of the Kuroshio responses from core CSH1, located at the northernmost site of the OT (Fig. 1). Our records of Kuroshio responses reconstructed here date back to Marine Isotope Stage (MIS) $5.1(\sim 88 \mathrm{ka})$; this is the longest record to date, with a resolution high enough to infer orbital- to millennial-scale climate and oceanographic changes in the northern OT.

\section{Oceanographic background}

The OT is a back-arc basin of the Ryukyu trench-arc-basin system (Lee et al., 1980). It is bounded by the Ryukyu Ridge and Trench to the east and the wide shelf of the East China Sea (ECS) to the west. The entire complex is arcuate, convex toward the Pacific with a NNE-SSW alignment from Japan to Taiwan (Lee et al., 1980). The OT is a big graben, consisting of the topographic depression behind the Ryukyu Arc with a length of $1200 \mathrm{~km}$ and a width of 100 $150 \mathrm{~km}$. Since the middle Miocene with the opening of the OT (Sibuet et al., 1987), it has been a depositional center in the ECS and has received a very large supply of sediment from nearby continents.

The modern hydrographic characteristics of surface water masses in the OT are controlled by the Yangtze River runoff

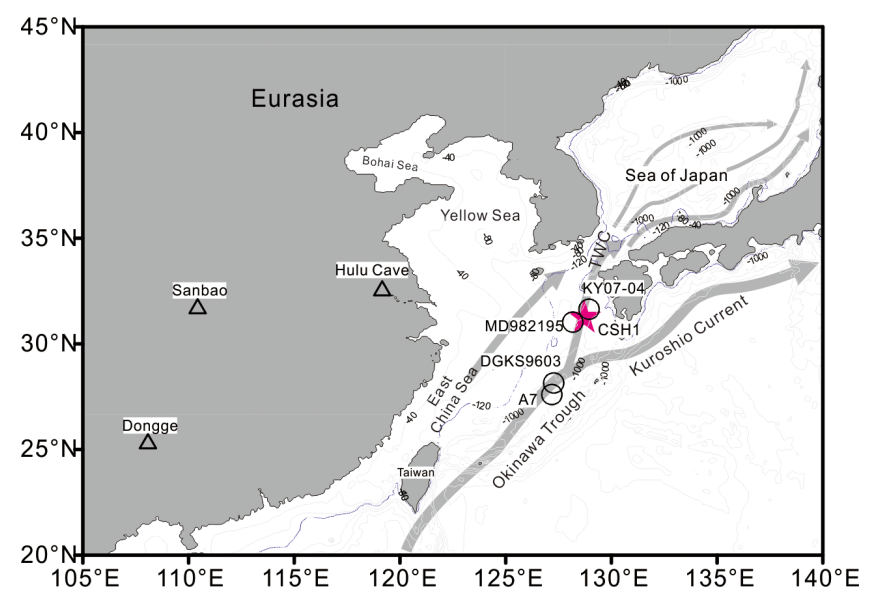

Figure 1. The pink star indicates core CSH1. The open circles means other cores mentioned in this study and the triangles denote the stalagmite caves in East China. Arrows denote simplified surface currents in the study region. The blue dashed curve stands for the $-120 \mathrm{~m}$ isobath.

and the Kuroshio (Lie and Cho, 2002). The Yangtze River carries huge amount of terrigenous materials and nutrients into the OT (Lie et al., 2003), which are responsible for the high surface productivity in the ECS. The Kuroshio is characterized by a high temperature and high salinity. After separating from the North Equatorial Current (Sawada and Handa, 1998), it flows across the Philippine Sea and along the east of Taiwan, entering the OT and flowing northwards along the trough. In the northern OT and the southern Kyushu, the main axis of the Kuroshio turns eastward, crosses the Ryukyu Arc through the Tokara Strait and then continues to flow northeastwardly into the northwestern Pacific Ocean at $\sim 38^{\circ} \mathrm{N}$. Another branch of the Kuroshio, the TWC, flows into the Sea of Japan through the Tsushima Strait. Because of the strong intrusion of the Kuroshio, the hydrographies are characterized by high temperature and salinity as well as a great depth of the thermocline (DOT) in the OT (Jian et al., 2000a). In contrast, the hydrographies are characterized by lower temperature and salinity and shallow DOT in the adjacent ECS shelves.

In our study area, the instrumental hydrographic records of the past century (1874-2002) show high temperature and low salinity in the upper water column $(<100 \mathrm{~m})$ in boreal summer (Fig. 2). Below $100 \mathrm{~m}$, the seasonal ranges of water temperature and salinity show only small changes. Previous investigations showed that the Changjiang River plume could move eastward over $400 \mathrm{~km}$ offshore across the wide shelf of the northern East China Sea when southerly winds prevail (Lie et al., 2003). 
Table 1. Details of age controlling points of accelerator mass spectrometry radiocarbon $\left(\mathrm{AMS}{ }^{14} \mathrm{C}\right)$ and $\delta^{18} \mathrm{O}$ of planktonic foraminifera in core CSH1 used for age model reconstruction.

\begin{tabular}{lllrlrrl}
\hline $\begin{array}{l}\text { Depth } \\
(\mathrm{cm})\end{array}$ & Materials & $\begin{array}{l}\text { AMS }{ }^{14} \mathrm{C} \\
(\mathrm{yr})\end{array}$ & $\begin{array}{r}\text { Error } \\
(\mathrm{yr})\end{array}$ & Range $(1 \delta)$ & $\begin{array}{r}\text { Calibrated age } \\
(\mathrm{cal} \text { yr BP })\end{array}$ & $\begin{array}{r}\text { Sedimentation rate } \\
\left(\mathrm{cm} \mathrm{ka}^{-1}\right)\end{array}$ & Source \\
\hline 10 & N. dutertrei & 3420 & \pm 35 & $3261-3339$ & 3301 & & \\
106 & N. dutertrei & 7060 & \pm 40 & $7500-7580$ & 7542 & 22.6 & this study \\
150 & N. dutertrei & 10840 & \pm 50 & $12220-12392$ & 12328 & 9.2 & this study \\
318 & N. dutertrei & 15130 & \pm 80 & $17718-18029$ & 17913 & 30.1 & Chen et al. (2006) \\
362 & mixing species & 16990 & \pm 140 & $19476-19510$ & 19746 & 24.0 & Chen et al. (2006) \\
558 & N. dutertrei & 20650 & \pm 120 & $23975-24339$ & 24161 & 44.4 & this study \\
678 & mixing species & 22430 & \pm 240 & $26084-26805$ & 26472 & 51.9 & Chen et al. (2006) \\
742 & N. dutertrei & 25440 & \pm 210 & $29644-29746$ & 29904 & 18.6 & this study \\
850 & N. dutertrei & 27810 & \pm 290 & $31283-31789$ & 31572 & 64.7 & this study \\
1002 & mixing species & 34050 & \pm 850 & $37152-39359$ & 38414 & 22.2 & Chen et al. (2006) \\
1058 & MIS 3.13 & & \pm 4710 & & 43880 & 10.2 & this study \\
1210 & MIS 3.3 & & \pm 3850 & & 50200 & 24.1 & this study \\
1282 & MIS 3.31 & & \pm 5030 & & 55450 & 13.7 & this study \\
1346 & MIS 4.22 & & \pm 6350 & & 64090 & 7.4 & this study \\
1530 & MIS 5 & & \pm 2590 & & 73910 & 18.7 & this study \\
1610 & MIS 5.1 & & \pm 3580 & & 79250 & 15.0 & this study \\
\hline
\end{tabular}

\section{Materials and methods}

The core CSH1 $\left(31^{\circ} 13.7^{\prime} \mathrm{N}, 128^{\circ} 43.4^{\prime} \mathrm{E}\right.$, water depth $703 \mathrm{~m}$ ), which has with a length of $17.3 \mathrm{~m}$, was taken from the northern OT using a piston corer during the Xiang Yang Hong Cruise in 1998. The sediments of the core mainly consist of black-gray and gray silt or clayey silt, with shell fragments and foraminifera occurring throughout the core $(\mathrm{Ge}$ et al., 2007). Initial core descriptions for CSH1 indicated that the core is continuous without interruption by any visible turbidites but contains three volcanic ash layers (Ge et al., 2007; Wu et al., 2004). In this study, we performed highresolution sampling at $4 \mathrm{~cm}$ intervals that resulted in a total of 434 samples for this analysis. Based on our accelerator mass spectrometry (AMS) ${ }^{14} \mathrm{C}$ dating and $\delta^{18} \mathrm{O}$ stratigraphy of planktonic foraminifera (Table 1), the bottom age of CSH1 is $\sim 88 \mathrm{ka}$, equivalent to MIS 5.1 (Fig. 3).

\subsection{Grain size analysis}

The sediment grain size was measured by Malvern MS2000 laser diffraction in the Key Laboratory of Marine Sedimentology and Environment Geology in the First Institute of Oceanography, State Oceanic Administration (SOA). The equipment has a dynamic range of $0.02-2000 \mu \mathrm{m}$ with a resolution of $0.01 \varphi$. After removing the organic matter $(10 \%$ $\mathrm{H}_{2} \mathrm{O}_{2}$ ) and carbonate $(1 \mathrm{M} \mathrm{HCl})$ from the sediment samples, the residual samples were standing for $12 \mathrm{~h}$ to make it fully precipitate. The residuals were then measured for grain size analysis after adding into sodium hexametaphosphate.

\subsection{Planktonic foraminiferal fauna analysis}

The samples for planktonic foraminiferal fauna analysis was first dried in the oven at $50^{\circ} \mathrm{C}$, weighed and then placed in water for $72 \mathrm{~h}$. The samples were washed through a $63 \mu \mathrm{m}$ sieve to remove the fine fraction and the identification of planktonic foraminiferal fauna specimens was done based on census counting of at least 300 specimens $>154 \mu \mathrm{m}$. All 26 species of planktonic foraminifera were identified and the relative abundances of each planktonic foraminiferal species were calculated based on the classification scheme (Table 2).

\subsection{Analysis for $\delta^{18} \mathrm{O}, \delta^{13} \mathrm{C}$ and $\mathrm{AMS}^{14} \mathrm{C}$}

Stable oxygen and carbon isotopes $\left(\delta^{18} \mathrm{O}\right.$ and $\left.\delta^{13} \mathrm{C}\right)$ of 199 downcore samples were measured using $\sim 30$ specimens of planktonic foraminifera Globigerinoides ruber and an Isoprime stable isotope mass spectrometer at Bremen University. The analysis error for $\delta^{18} \mathrm{O}$ and $\delta^{13} \mathrm{C}$ is $<0.06$ and $0.03 \%$, respectively.

AMS ${ }^{14} \mathrm{C}$ ages were measured based on analysis of $\sim 500$ specimens of Neogloboquadrina dutertrei $(>150 \mu \mathrm{m})$ at 12 stratigraphic horizons using the AMS at the Leibniz Laboratory for Radiometric Dating and Isotope Research, Kiel (Table 1).

\subsection{Alkenone sea surface temperature (SST) analysis}

Dried and homogenized sediment samples were extracted three times using a mixture of dichloromethane and methanol (97:3). The unsaturated alkenones were isolated from sediment extracts dried using rotary evaporation and saponified with a $0.5 \mathrm{M}$ solution of $\mathrm{KOH}$ in $\mathrm{MeOH}$. After drying under 
Table 2. Descriptive statistics of planktonic foraminiferal species and Q-mode varimax factor analysis for core CSH1.

\begin{tabular}{|c|c|c|c|c|c|c|c|c|}
\hline & $\mathrm{SD}(\%)$ & $\operatorname{Min}(\%)$ & Average $(\%)$ & $\operatorname{Max}(\%)$ & $\mathrm{F} 1$ & F2 & F3 & $\mathrm{F} 4$ \\
\hline Orbulina universa & 1.57 & 0 & 0.24 & 0.26 & 0.03 & 0.16 & 0.05 & 0.29 \\
\hline Globigerinoides conglobatus & 1.03 & 0 & 0.1 & 0.17 & -0.05 & 0.51 & -0.16 & 0.17 \\
\hline Globigerinoides ruber & 22.34 & 5.25 & 11.59 & 3.28 & 0.10 & 0.94 & 0.01 & 0.14 \\
\hline Globigerinoides tenellus & 3.52 & 0 & 1.04 & 0.66 & 0.09 & 0.71 & 0.09 & -0.03 \\
\hline Globigerinoides sacculifer & 5.35 & 0.17 & 1.7 & 1.14 & -0.04 & 0.54 & -0.22 & 0.17 \\
\hline Globigerinella aequilateralis & 2.62 & 0 & 0.37 & 0.42 & -0.03 & 0.43 & -0.32 & 0.15 \\
\hline Gloigerina calida & 2.82 & 0 & 0.68 & 0.61 & -0.06 & 0.47 & -0.28 & 0.11 \\
\hline Globigerina bulloides & 53.79 & 9.4 & 22.4 & 7.93 & 0.98 & 0.13 & 0.17 & -0.05 \\
\hline Globigerina falconensis & 5.38 & 0 & 1.39 & 1.19 & -0.01 & 0.10 & 0.05 & 0.14 \\
\hline Globigerina digitata & 0.4 & 0 & 0.01 & 0.05 & -0.03 & 0.18 & -0.15 & -0.01 \\
\hline Globigerinoides rubescens & 2.22 & 0 & 0.68 & 0.5 & 0.20 & 0.71 & 0.09 & -0.05 \\
\hline Globigerina quinqueloba & 8.86 & 0 & 2.34 & 1.43 & 0.11 & 0.32 & 0.58 & -0.08 \\
\hline Neogloboquadrina pachyderma (sin.) & 0.67 & 0 & 0.1 & 0.14 & 0.01 & -0.14 & 0.45 & 0.04 \\
\hline Neogloboquadrina pachyderma (dex.) & 25.89 & 0.14 & 10.49 & 5.8 & -0.08 & -0.20 & 0.96 & 0.16 \\
\hline$N$ dutertrei & 34.52 & 8.28 & 21.59 & 5.69 & 0.07 & 0.13 & 0.44 & 0.88 \\
\hline Globoquadrina conglomerata & 0.67 & 0 & 0.02 & 0.08 & -0.11 & -0.01 & 0.10 & 0.07 \\
\hline Pulleniatina obliquiloculata & 6.79 & 0 & 1.8 & 1.45 & 0.00 & 0.62 & -0.40 & 0.38 \\
\hline Globorotalia inflata & 11.26 & 0.18 & 4.9 & 2.64 & -0.11 & -0.03 & -0.05 & 0.52 \\
\hline Globorotalia truncatulinoides (sin.) & 0.73 & 0 & 0.05 & 0.12 & -0.06 & -0.07 & -0.10 & 0.34 \\
\hline Globorotalia truncatulinoides (dex.) & 2.04 & 0 & 0.27 & 0.35 & 0.04 & -0.15 & 0.32 & 0.01 \\
\hline Globorotalia crassaformis & 5.74 & 0 & 0.95 & 0.76 & 0.02 & 0.33 & -0.09 & 0.05 \\
\hline Globorotalia menardii & 1.11 & 0 & 0.17 & 0.23 & 0.04 & 0.33 & -0.35 & 0.32 \\
\hline Globigerinita glutinata & 25.03 & 1.08 & 6.99 & 5.05 & 0.16 & 0.95 & -0.17 & -0.15 \\
\hline$\%$ of Variance & & & & & 44.84 & 22.88 & 15.73 & 12.28 \\
\hline Cumulative $\%$ & & & & & 44.84 & 67.72 & 83.46 & 95.74 \\
\hline
\end{tabular}

Note: High factor loading (bold type) indicates the primary species contributing to each factor.
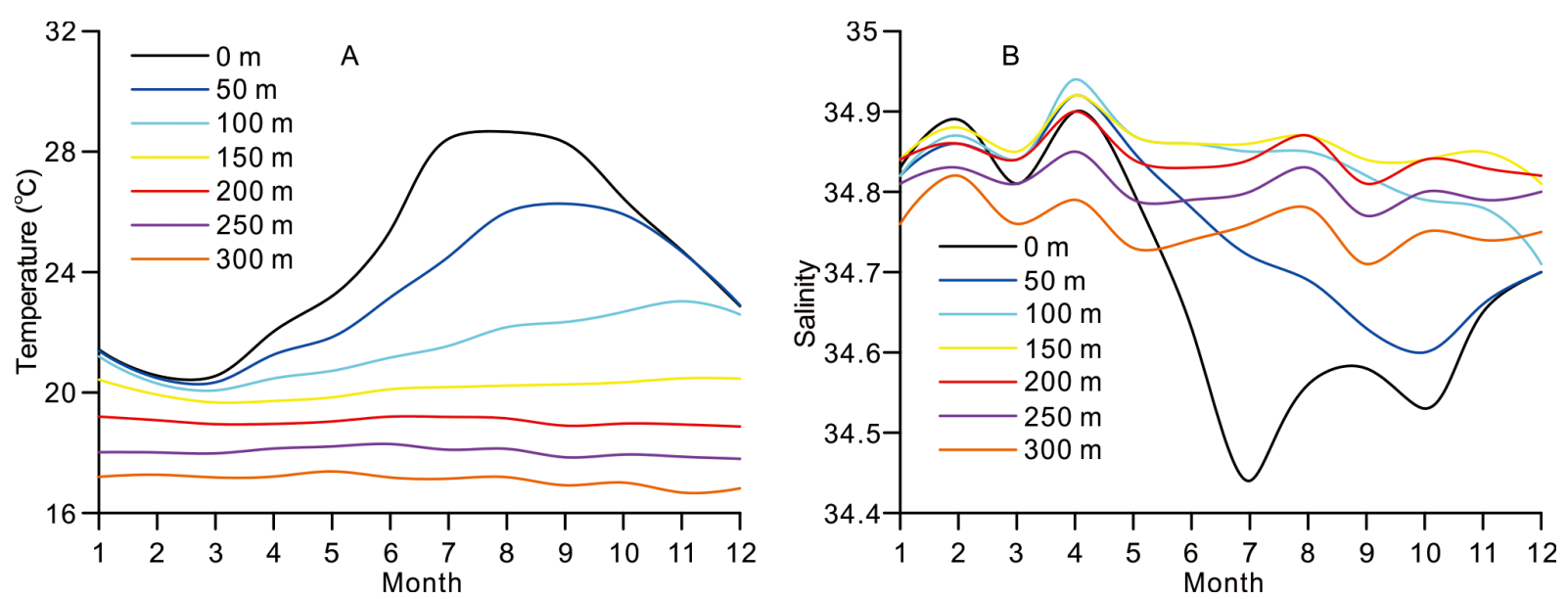

Figure 2. Monthly temperature and salinity for the upper $400 \mathrm{~m}$ of the water column in the northern Okinawa Trough at $131-132^{\circ} \mathrm{E}$ and $28-29^{\circ}$ N. (Data source: JODC (Japan Oceanographic Data Center) Data On-line Service System).

nitrogen gas, the extracts were separated into four fractions using column chromatography. $\mathrm{N}-\mathrm{C}_{36} \mathrm{H}_{74}$ was added as an internal standard to alkenone. Unsaturated alkenones were analyzed using a HP6890 Gas chromatography with oncolumn injection, an electronic pressure control system and a flame ionization detector. The experimental procedures of using a gas chromatography (GC) column and setting up an oven temperature as well as carrier pressure programs were reported by Xing et al. (2008). The long-chain unsaturated alkenones were measured at the China Ocean University. SST was calculated using the following equations 

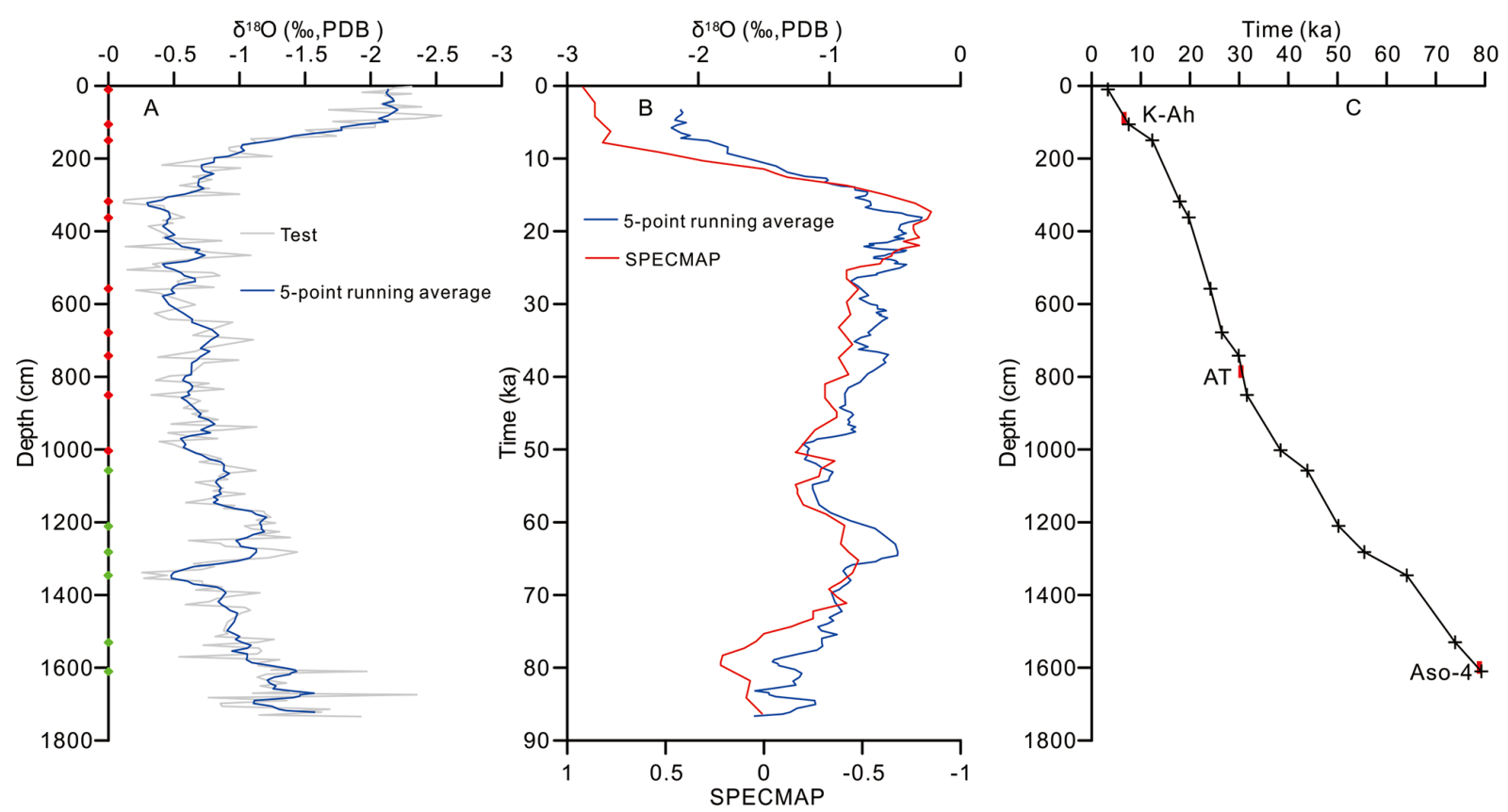

Figure 3. (a) $\delta^{18} \mathrm{O}$ of planktonic foraminifera G.ruber plotted against depth $(\mathrm{cm})$ for core $\mathrm{CSH} 1$. The age control point for $\mathrm{AMS}{ }^{14} \mathrm{C}$ and $\delta^{18} \mathrm{O}$ are indicated by the red and green diamonds, respectively. (b) Five-point running average $\delta^{18} \mathrm{O}$ of planktonic foraminifera $G$. ruber for core CSH1 and the SPECMAP (Spectral Maping Project) curve (Martinson et al., 1987) plotted against age over the last $88 \mathrm{ka}$. (c) Plot of measured ages vs. depth for core CSH1. The three known ash layers are indicated by solid red rectangles.

(Muller et al., 1998):

$U_{37}^{k^{\prime}}=C_{37: 2 \mathrm{Me}} /\left(C_{37: 2 \mathrm{Me}}+C_{37: 3 \mathrm{Me}}\right)$,

$\operatorname{SST}\left({ }^{\circ} C\right)=\left(U_{37}^{k^{\prime}}-0.044\right) / 0.033$.

The analytical error for $U_{37}^{k^{\prime}}$ is 0.006 , which translates into an error of $0.2^{\circ} \mathrm{C}$ in estimating SST.

\subsection{Salinity}

The planktonic foraminifera $\delta^{18} \mathrm{O}\left(\delta^{18} \mathrm{O}_{\mathrm{pf}}\right)$ is controlled by seawater $\delta^{18} \mathrm{O}\left(\delta^{18} \mathrm{O}_{\mathrm{sw}}\right)$ and local SST. In the northern OT, higher contents of unsaturated alkenones, observed in the upper water column of $\sim 20 \mathrm{~m}$, and the estimated temperature are consistent with the modern observation based on the sediment trap samples (Nakanishi et al., 2012). Coccolithophore fluxes are high throughout the year, except for the summer season in the ECS (Tanaka, 2003). Therefore, alkenone-derived SST could be used to obtain annual mean SSS (sea surface salinity) estimates in the northern OT. For G. ruber, Mulitza et al. (2004) established the following correlation between temperature and $\delta^{18} \mathrm{O}$ :

$$
\begin{aligned}
& T=14.32-4.28 \times\left(\delta^{18} \mathrm{O}_{\mathrm{pf}}-\delta^{18} \mathrm{O}_{\mathrm{sw}}\right) \\
& +0.07\left(\delta^{18} \mathrm{O}_{\mathrm{pf}}-\delta^{18} \mathrm{O}_{\mathrm{sw}}\right)^{2},
\end{aligned}
$$

where $\delta^{18} \mathrm{O}_{\mathrm{sw}}$ is related to local SST, evaporation and precipitation. In the areas influenced by the Kuroshio, there is the following relationship between salinity and $\delta^{18} \mathrm{O}_{\mathrm{sw}}(\mathrm{Oba}, 1988)$ :

$\delta^{18} \mathrm{O}_{\mathrm{sw}}=0.203 \times S S S-6.76$.

In 2006, a total of 317 seawater samples collected from the Yellow Sea and ECS were analyzed for salinity and $\delta^{18} \mathrm{O}_{\mathrm{sw}}$, which resulted in the following correlation (Du et al., 2012):

$\delta^{18} \mathrm{O}_{\mathrm{sw}}=0.29 \times S S S-9.85$

The $\delta^{18} \mathrm{O}$ values in the water from the Yangtze and Yellow rivers range from $\sim-8.8$ to $-7.1 \%$ o (Zhang et al., 1990), which is consistent with the intercepts in Eqs. (4) and (5), and therefore both Eqs. (4) and (5) are considered as a mixing between local runoff and seawater in the marginal seas. After removing the effect of global ice volume on $\delta^{18} \mathrm{O}_{\mathrm{sw}}$ (Bintanja et al., 2005), the salinity in core CSH1 was calculated. The conversion relationship for $\delta^{18} \mathrm{O}$ of calcite relative to Vienna Pee Dee Belemnite (VPDB) is as follows (Coplen, 2007):

$\delta^{18} \mathrm{O}_{\mathrm{V}-\mathrm{SMOW}}=1.03092 \times \delta^{18} \mathrm{O}_{\mathrm{PDB}}+30.917 \%$.

In order to minimize the errors of $\delta^{18} \mathrm{O}$ subtraction from two isotope records, the raw data were smoothed using a five-point running average procedure. The salinity calculated based on both Eqs. (4) and (5) shows a similar trend. Here, we use Eq. (5) to calculate the CSH1 SSS record. 


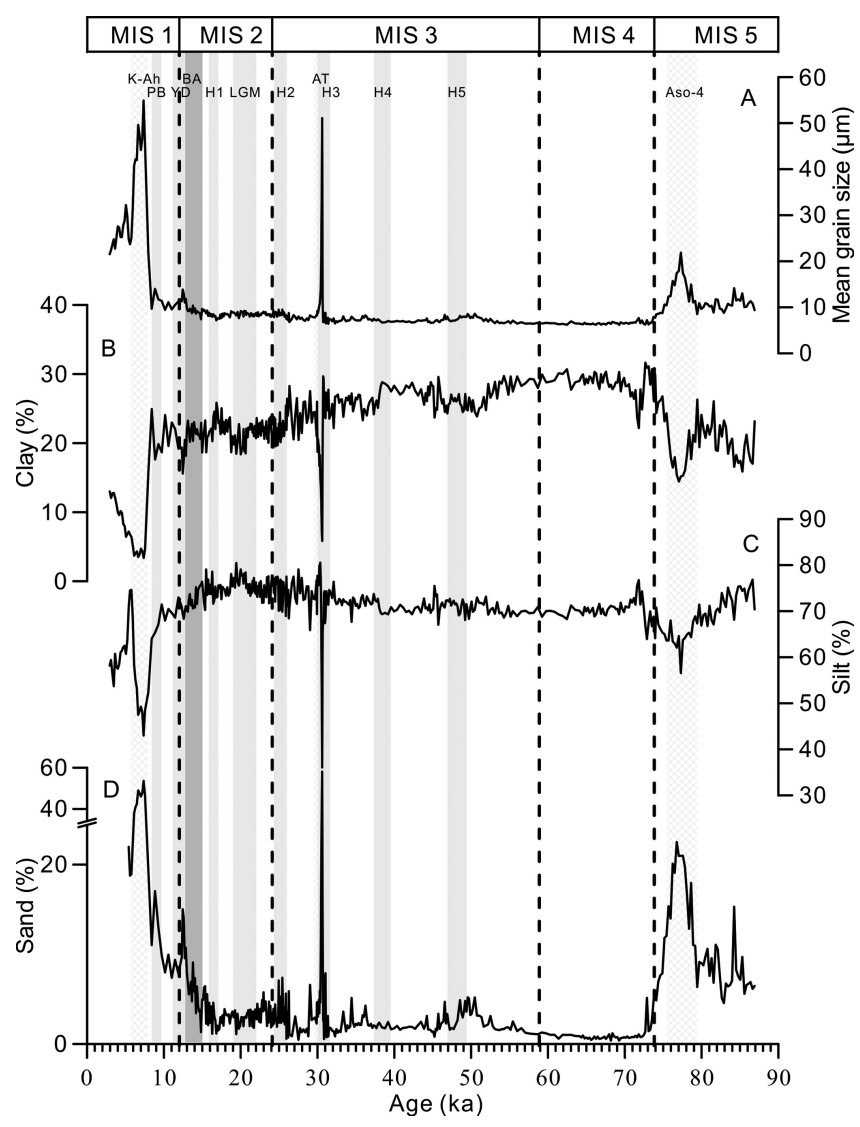

Figure 4. Time series plots for contents of sand, silt and clay and the mean grain size. Gray bars indicate the intervals of important climatic events. MIS 1, 2, 3, 4 and 5 represent marine isotope stages. K-Ah, AT and Aso-4 refer to well-known ash layers, recorded across a wide spread of the Sea of Japan and the northern Okinawa Trough and indicated by the gray bars filled with diagonal cross. PB, YD, BA, H1, H2, LGM, H3, H4 and H5 refer to Preboreal, Younger Dryas, Bølling-Allerød, Heinrich 1, Heinrich 2, Last Glacial Maximum, Heinrich 3, Heinrich 4 and Heinrich 5, respectively.

\subsection{Age model}

The age model for CSH1 was built by AMS ${ }^{14} \mathrm{C}$ and planktonic foraminifera $\delta^{18} \mathrm{O}$ SPECMAP (Spectral Maping Project) age controls (Fig. 3a). In the upper $1002 \mathrm{~cm}$, the age control points were determined by $\mathrm{AMS}^{14} \mathrm{C}$, while below $1002 \mathrm{~cm}$, the age model was constructed by SPECMAP chronology (Table 2). A preliminary age model of the last $40 \mathrm{ka}$ for core CSH1 was built using four $\mathrm{AMS}^{14} \mathrm{C}$ data based on mixing planktonic foraminiferal specimens (Chen et al., 2006). In this study, we constructed a more precise age model by picking up single species $N$. dutertrei for AMS ${ }^{14} \mathrm{C}$ dating from 12 samples, of which five AMS ${ }^{14} \mathrm{C}$ dating below the core depth $1002 \mathrm{~cm}$ are older than $40 \mathrm{ka}$ and are unused. All other $\mathrm{AMS}^{14} \mathrm{C}$ dates show no reversals (Table 2). Combined with previously reported $4 \mathrm{AMS}^{14} \mathrm{C}$ dates, all $11 \mathrm{AMS}^{14} \mathrm{C}$ ages were calibrated to the calendar year by a correction for an average surface ocean carbon reservoir of 400 years (Calib 6.1) (Reimer et al., 2009). Considering that the calibrated calendar age $(12.384-12.491 \mathrm{ka})$ at $178 \mathrm{~cm}$ conflicts slightly with the age at $158 \mathrm{~cm}(12.220-12.392 \mathrm{ka})$, the age at $178 \mathrm{~cm}$ is not adopted here. Finally, a total of $10 \mathrm{AMS}^{14} \mathrm{C}$ ages were used as age control points for the upper $1002 \mathrm{~cm}$ in CSH1.

The $\delta^{18} \mathrm{O}$ curve of $G$. ruber shows good correlation with the SPECMAP (Martinson et al., 1987) (Fig. 3b), which allows us to identify MIS 1-5.1 (Table 1). The existence of three ash layers provides independent age controls. The sediment grain size and susceptibility are increased at the ash layers (Ge et al., 2007). Based on the heavy mineral composition, morphology and refractive index of volcanic glass, the first two ash layers are considered as being K-Ah (6.1$7.5 \mathrm{ka})$ and AT (30-35 ka) (Machida, 1999), layers which are widely distributed in the Sea of Japan and the OT. The bottom ages of the two ash layers are consistent with previous results $-7.54 \mathrm{ka}(108 \mathrm{~cm})$ and $30.67 \mathrm{ka}(796 \mathrm{~cm})$, respectively. The third ash layer is recognized as Aso-4 (MIS 5.1/5.2) (Machida, 1999). However, our isotope age model indicates that the bottom of the third ash layer dates to $\sim 79.44 \mathrm{ka}$ $(1616 \mathrm{~cm})$, which is slightly younger than the absolute dating for Aso-4 (84-89 ka) (Machida, 1999). The age difference might result from the internal discrepancy between the $\mathrm{K}$-Ar dating method and SPECMAP chronology and does not affect our interpretation of the records.

Our combined AMS ${ }^{14} \mathrm{C}$, SPECMAP $\delta^{18} \mathrm{O}$ and volcanic ash layer chronology generates an estimated bottom age of $\sim 87.4 \mathrm{ka}$ for CSH1 (Fig. 3c) with an averaged sampling resolution of $\sim 200$ years. The calculated linear sedimentation rate (LSR) varies from $>40 \mathrm{~cm} \mathrm{ka}^{-1}$ during MIS 2 and MIS 3 to $<10 \mathrm{~cm} \mathrm{ka}^{-1}$ in the last deglaciation $(7.5-12.3 \mathrm{ka})$ and MIS 4 (55.5-64.1 ka).

\section{Results}

\subsection{Grain size analysis}

The grain size analysis reveals that the sediment mainly consists of silt and clayey silt, which varies between 36 and $81 \%$ (Fig. 4). Except for the volcanic ash layers, the mean grain size increased during MIS 5.1 and from the last deglacial period onwards(Fig. 4a). In ash layers, the sand content increases significantly, while clay and silt contents decrease (Fig. 4b, c and d). The frequency distribution for sediment grain size shows a single peak in normal sediment layers, while a bimodal peak is shown in the ash layers.

\subsection{Planktonic foraminiferal assemblages}

A total of 27 planktonic foraminiferal species were identified and counted; the average abundances of 11 of these species are $>1 \%$. These 11 species constitutes $86 \%$ of the planktonic foraminiferal assemblage. From high- to 


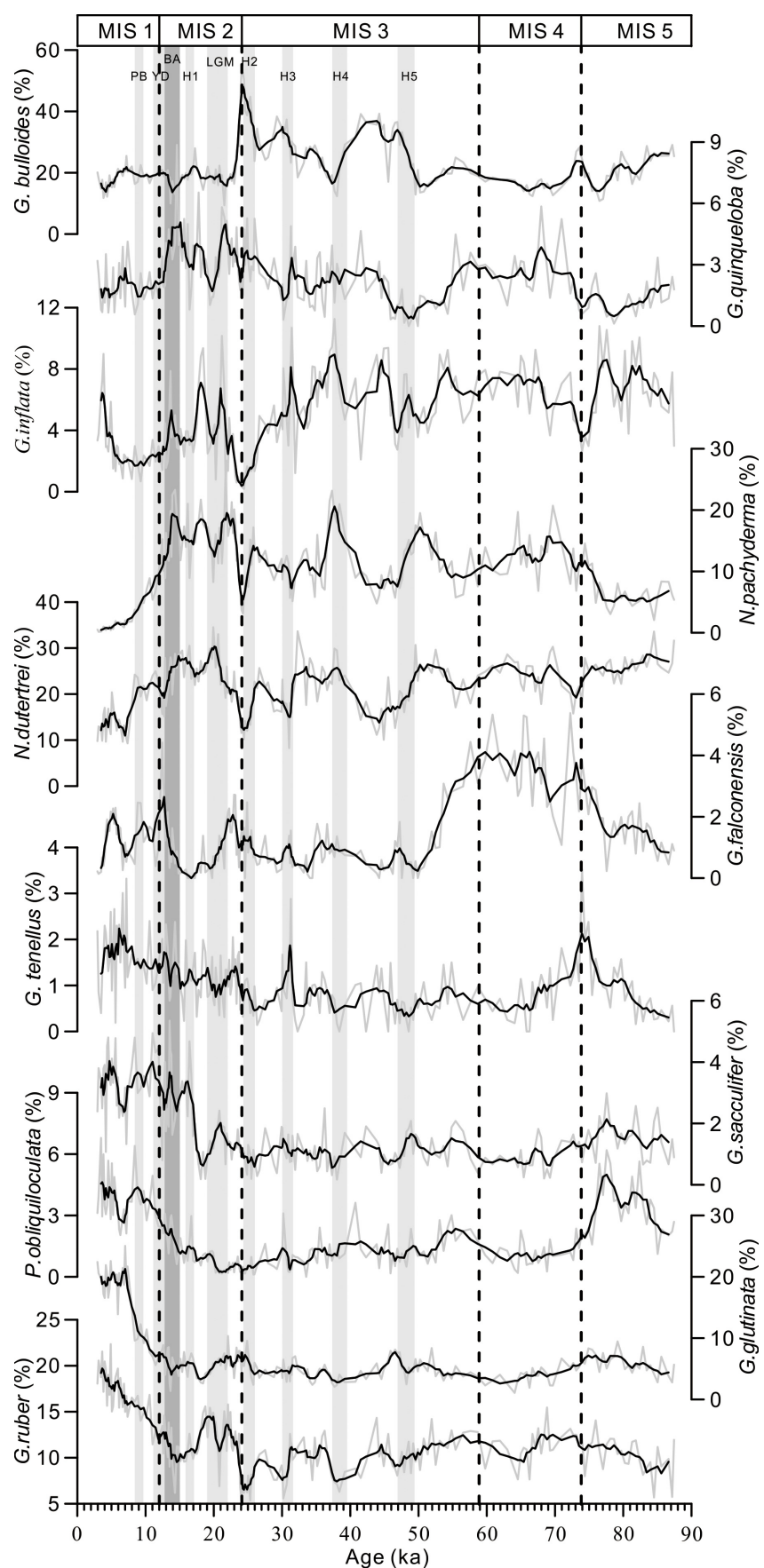

Figure 5. Time series plots for the abundances of dominant species of planktonic foraminifera in core CSH1. Gray bars are the same as those in Fig. 4.

low-average abundances, they are Globigerina bulloides, $N$. dutertrei, G. ruber, Neogloboquadrina pachyderma (dex.), Globigerinita glutinata, Globorotalia inflata, Globigerina quinqueloba, Pulleniatina obliquiloculata, Globigerinoides sacculifer, Globigerina falconensis and Globigerinoides tenellus (Table 2).
The planktonic foraminiferal assemblage in CSH1 consists of many cold-water species. For example, $N$. dutertrei mainly lives in the thermocline below the mixed layer and is a dominant species in core CSH1 with an average value of $21.6 \%$. The highest abundances of $N$. dutertrei occurred during the LGM (Last Glacial Maximum) (26.6\%) and MIS 5.1 (26.2\%), while lower abundances appeared during MIS 1 $(15 \%)$ (Fig. 5; Table 2). In the tropical and subtropical Atlantic, higher abundances of $N$. dutertrei are mainly related to upwelling (Pflaumann et al., 1996) and are indicative of the upwelling zones in the South China Sea (SCS) (Pflaumann and Jian, 1999). N. pachyderma (dextral), is a coldwater species dominant in the Arctic and subarctic oceans (Hemleben et al., 1989). In core CSH1, the abundances of N. pachyderma (dextral) were $2.5 \%$ and $6.7 \%$ during MIS 1 and MIS 5.1, respectively; while during MIS 2, MIS 3 and MIS 4, its abundances were relatively high with $15.3 \%$, $11.3 \%$ and $12.7 \%$, respectively. Except during MIS 5.1, abundances of $N$. pachyderma (dextral) were well paralleled with $N$. dutertrei. The abundances of $G$. quinqueloba were higher during MIS 2 and MIS 4 than during MIS 1 and MIS 5.1, with an average value of $2.3 \%$; they also show a similar trend with $N$. pachyderma (dextral) (Fig. 5). G. inflata is a "gyre margin" species in the world ocean (Hemleben et al., 1989), and the high abundances of $G$. inflata occur at the convergence zone between the Kuroshio and subpolar water mass in the western Pacific (Thompson, 1981). In core CSH1, the abundances of $G$. inflata were lower during MIS 1 $(3.1 \%)$ and MIS $2(3.7 \%)$ than those in MIS $3(5.5 \%)$, MIS 4 (6.6\%) and MIS 5.1 (6.5\%) (Fig. 5).

Among warm-water species in CSH1, G. ruber is the most dominant and shows high abundances during interglacials and low abundances during glacials (Fig. 5). The G. ruber abundances gradually increased from $16 \mathrm{ka}$ onwards and reached a maximum in the mid-Holocene. The $G$. ruber abundances decreased during $\mathrm{H}$ events, but were relatively high during the LGM. Another warm-water species, G. glutinata shows a similar pattern to $G$. ruber. The average abundances of the warm-water species $P$. obliquiloculata and $G$. sacculifer are $<2 \%$, but show similar patterns to $G$. ruber. However, the abundances of $P$. obliquiloculata were characterized by maxima during MIS 5.1, which were not seen in other warm-water species (Fig. 5).

The presence of G. bulloides and Globorotalia truncatulinoides in CSH1 indicate changes in upwelling. G. bulloides is dominant with an averaged abundance of $22.4 \%$, second only to $N$. dutertrei. Interestingly, the abundances of $G$. bulloides reached maxima during MIS $3(27.8 \%)$ and minima during MIS 1, MIS 2, MIS 4 and MIS 5.1 (Fig. 5). The average abundances of $G$. truncatulinoides are relatively low in CSH1, but, interestingly, show morphotype changes in coiling directions. The sinistral morphotype was dominant from 51 to $88 \mathrm{ka}$, while the dextral was more dominant after $51 \mathrm{ka}$ (Fig. 7). Since the Holocene, the abundances of dextral have 


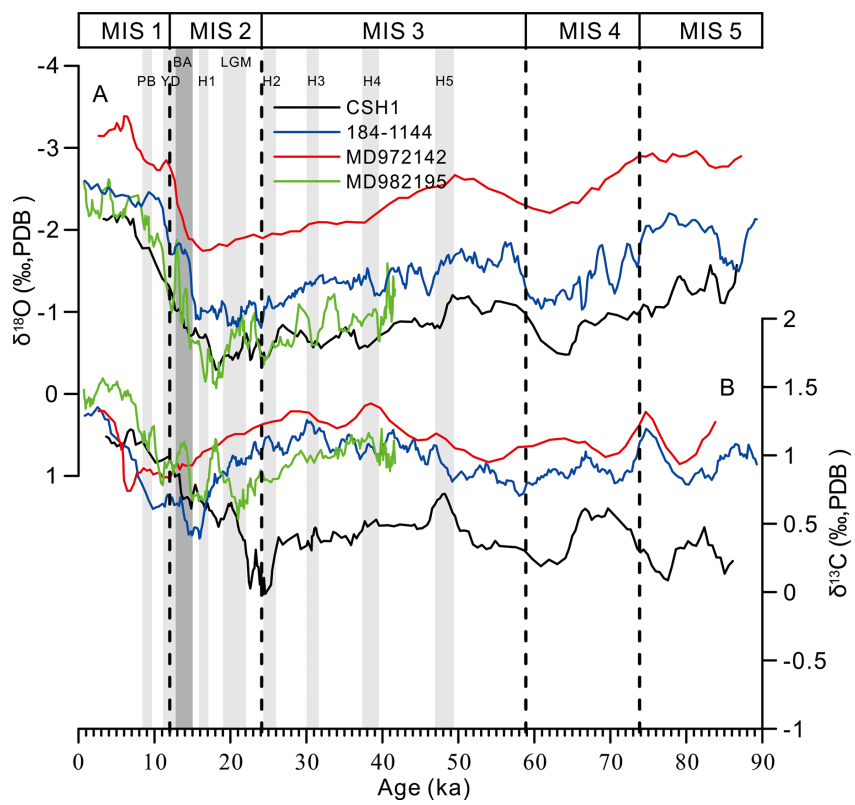

Figure 6. Time series plots of $\delta^{18} \mathrm{O}$ and $\delta^{13} \mathrm{C}$ of planktonic foraminifera, contrasted with the records in cores MD982195 (Ijiri et al., 2005), MD972142 (Chen et al., 2003) and Site 184-1144 (Buhring, 2001). Gray bars are the same as those in Fig. 4.

decreased and they were rarely found from 4 to $8 \mathrm{ka}$, consistent with the previous study from the SCS (Jian et al., 2000b).

In order to reveal the correlation between the abundances of planktonic foraminiferal species, a Q-mode varimax factor analysis was used based on the abundance data of planktonic foraminiferal species from core $\mathrm{CSH} 1$, and four factors that explain $96 \%$ of the total variance were extracted (Table 2). Factor 1 explains $45 \%$ of the total variance and is composed solely of the upwelling species, G. bulloides. Factor 2 explains $23 \%$ of the total variance and is mainly composed of numerous warm-water species - G. ruber, G. conglobatus, G. rubescens, G. tenellus, G. glutinata, G. sacculifer and $P$. obliquiloculata. Factor 3 explains $16 \%$ of the total variance and consists of cold-water species - G. quinqueloba and $N$. pachyderma. Factor 4 explains $12 \%$ of the total variance and is mainly composed of species indicative of a convergence zone between water masses $-N$. dutertrei and $G$. inflata.

\subsection{Stable carbon and oxygen isotopes of planktonic foraminifera}

The values of $\delta^{18} \mathrm{O}$ from $G$. ruber vary between -2.54 and $-0.11 \%$, and were heavier during MIS 2, MIS 3 and MIS 4 than those during MIS 1 and MIS 5.1 (Fig. 6a). The values of $\delta^{18} \mathrm{O}_{\text {ruber }}$ during MIS 1 were much heavier than those in MIS 5.1 (Fig. 6a), although SST values were close during both intervals. In spite of its high-frequency variation, $\delta^{18} \mathrm{O}_{\text {ruber }}$ with a five-point running average in core CSH1 matches well with the SPECMAP (Martinson et al., 1987),

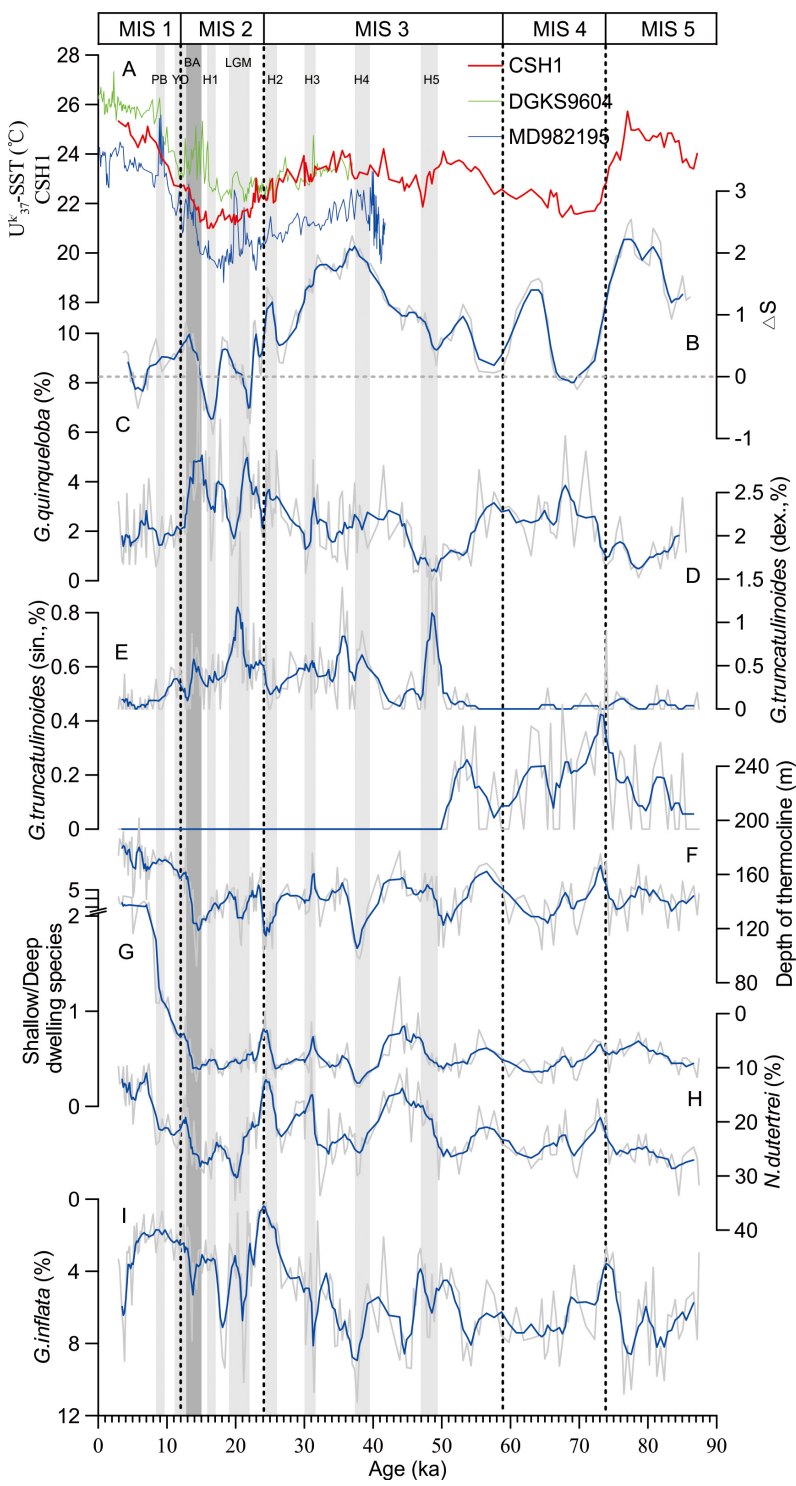

Figure 7. Time series plots of temperature, salinity, depth of the thermocline (DOT) and the ratio of shallow/deep species in core CSH1 as well as comparison with the abundances of G.quinqueloba, G.truncatulinoides, N.dutertrei and G.inflata in core CSH1 and other records in cores MD982195 (Ijiri et al., 2005) and DGKS9604 (Yu et al., 2009). Salinity values are given as the difference from the present-day climate, $\Delta \mathrm{S}$. Both the distributions of $N$. dutertrei and G.inflata are related to DOT, but they show different down-core profiles in core CSH1. Gray bars are the same as those in Fig. 4.

indicating that the first-order pattern of $\delta^{18} \mathrm{O}_{\text {ruber }}$ was driven by global ice volume. The $\delta^{18} \mathrm{O}_{\text {ruber }}$ has gradually decreased since $18 \mathrm{ka}$ and reached minima during the early Holocene (Fig. 6a). Such trends were also observed in previous results from cores MD982195 (Ijiri et al., 2005) and core A7 (Sun et al., 2005) in the northern and middle OT, ODP184-1144 
Table 3. Average SST and SSS from proxies of different periods for core CSH1 and from instrumental records in the study area around $28-29^{\circ} \mathrm{N}, 131-132^{\circ} \mathrm{E}$.

\begin{tabular}{|c|c|c|c|c|c|c|c|c|c|c|c|}
\hline & $T\left({ }^{\circ} \mathrm{C}\right)^{*}$ & $S^{*}$ & & $T\left({ }^{\circ} \mathrm{C}\right)$ & $S$ & & $T\left({ }^{\circ} \mathrm{C}\right)$ & $S$ & & $T\left({ }^{\circ} \mathrm{C}\right)$ & $S$ \\
\hline Jan & $21.43 \pm 0.83$ & $34.83 \pm 0.08$ & MIS 1 & 24.47 & 34.80 & PB & 24.13 & 35.02 & $\mathrm{H} 2$ & 22.4 & 35.72 \\
\hline Apr & $22.03 \pm 1.33$ & $34.90 \pm 0.12$ & MIS 2 & 21.75 & 34.78 & YD & 22.64 & 35.21 & H3 & 23.08 & 36.16 \\
\hline Jul & $28.43 \pm 1.08$ & $34.44 \pm 0.2$ & MIS 3 & 23.15 & 35.83 & BA & 22.06 & 35.12 & $\mathrm{H} 4$ & 23.11 & 36.66 \\
\hline Oct & $26.45 \pm 1$ & $34.53 \pm 0.12$ & MIS 4 & 22.02 & 35.20 & H1 & 21.06 & 34.00 & H5 & 22.88 & 35.32 \\
\hline Annual & $24.54 \pm 3.16$ & $34.68 \pm 0.19$ & MIS 5.1 & 24.33 & 36.42 & LGM & 21.5 & 34.64 & & & \\
\hline
\end{tabular}

Note: data $\left({ }^{*}\right)$ obtained from the JODC Data On-line Service System.

(Buhring, 2001) and MD972142 (Chen et al., 2003) in the SCS.

The value of $\delta^{13} \mathrm{C}_{\text {ruber }}$ ranges between -0.61 and $1.45 \%$ o with the lowest values in $\mathrm{H} 2(24 \mathrm{ka})$ and has gradually become heavier since then (Fig. 6b). The ${ }^{13} \mathrm{C}$ enrichment is also recorded in Site 184 (Buhring, 2001), MD972142 (Chen et al., 2003) and MD982195 (Ijiri et al., 2005). However, during MIS 5.1, $\delta^{13} \mathrm{C}_{\text {ruber }}$ showed reverse a trend, in contrast to Site ODP184 (Buhring, 2001) and core MD972142 (Chen et al., 2003). The $\delta^{13} \mathrm{C}$ value in planktonic foraminiferal shell is controlled by many factors, including the $\delta^{13} \mathrm{C}$ of the local seawater, vital effects, the habitat fauna species and postdepositional dissolution (Mulitza et al., 1999). The difference between $\delta^{13} \mathrm{C}$ curves from CSH1, Site ODP184 (Buhring, 2001) and MD972142 (Chen et al., 2003) suggests different surface ocean hydrology in the OT and SCS during MIS 5.1. From 6 to $20 \mathrm{ka}, \delta^{13} \mathrm{C}_{\text {ruber }}$ values in core DGKS9603 from the middle Okinawa Trough showed lighter values, which was interpreted as reflecting an invasion of oligotrophic tropical Pacific water (Li et al., 2002) but which was not observed in CSH1. This indicates a more complicated spatial pattern of $\delta^{13} \mathrm{C}$ in the seawater in the OT which is far beyond our current understanding.

\subsection{Alkenone SST}

In core CSH1, alkenone SST varies from 21 to $25^{\circ} \mathrm{C}$ with an average of $23^{\circ} \mathrm{C}$. The average SSTs during MIS 1 $\left(24.5^{\circ} \mathrm{C}\right)$ and MIS $5.1\left(24.4^{\circ} \mathrm{C}\right)$ were more or less similar and these values are much higher than MIS $2\left(21.8^{\circ} \mathrm{C}\right)$, MIS $3\left(23.1^{\circ} \mathrm{C}\right)$ and MIS $4\left(22^{\circ} \mathrm{C}\right)$ (Table 3$)$. The average SST since $8 \mathrm{ka}$ is close to the annual mean SST from instrumental observations near the site $\left(\sim 24.87^{\circ} \mathrm{C}\right)$ (Table 3$)$, indicating that the alkenone SST mainly reflects annual mean temperature. The CSH1 SSTs during MIS 2 and MIS 4 were similar and were lower than modern SST by $2.5^{\circ} \mathrm{C}$. During the LGM, the alkenone SST varied from 21 to $22^{\circ} \mathrm{C}$, with an average of $21.5^{\circ} \mathrm{C}$, which was lower than modern SST by $3.4^{\circ} \mathrm{C}$. Since $17 \mathrm{ka}$, the CSH1 alkenone SST values have increased rapidly from 21 to $25^{\circ} \mathrm{C}$. Compared to other SST records in cores DGKS9604 and MD982195 from the OT, the CSH1 SST record shows a similar pattern but is slightly higher than that of MD982195 (Ijiri et al., 2005) and lower than that of DGKS9604 (Yu et al., 2009) (Fig. 7a).

\subsection{Sea surface salinity}

Our SSS estimate for core CSH1 shows large fluctuations (Fig. 7b). During MIS 1 and MIS 2, the SSS was similar (34.8 and 34.8, respectively) (Table 3), consistent with the modern annual mean SSS (34.7) near this site. The SSS values were much higher in MIS 3 (35.8), MIS 4 (35.2) and MIS 5.1 (36.4), with maxima occurring during MIS 5.1 and mid-MIS 3 (Fig. 7b, Table 3). During cold periods, such as the LGM and $\mathrm{H}$ events/stadials, the SSS values increased. These high SSS values suggest less precipitation and/or river runoff relative to evaporation than today in the northern OT.

\subsection{Depth of the thermocline (DOT)}

Our DOT estimate using the planktonic foraminiferal transfer function (Andreasen and Ravelo, 1997) for CSH1, which is based on the spatial distribution of 189 core-top planktonic foraminifera in the tropical Pacific. The transfer function has a standard error of $22 \mathrm{~m}$ and an additional $5 \mathrm{~m}$ of error due to insufficient counts in the core top database. The result shows the changes of DOT vary from $>160 \mathrm{~m}$ during MIS 1 , and between $139 \mathrm{~m}$ and $141 \mathrm{~m}$ from MIS 2 to MIS 5.1 (Fig. 7f). DOT in core CSH1 rapidly increased from $15 \mathrm{ka}$ onwards but abruptly decreased during the LGM, $\mathrm{H}$ events/stadials, consistent with what has been observed from the middle OT (Xiang et al., 2007). Our DOT estimate is also consistent with the implications of the changes in planktonic foraminiferal assemblages (Ravelo and Fairbanks, 1992; Ravelo et al., 1990; Thunell et al., 1983). Planktonic foraminiferal species G. ruber, G. sacculifer and G. glutinata are shallow-water species and their abundances increased with deeper DOT. $N$. dutertrei and $N$. pachyderma live below the thermocline, and when the DOT becomes shallower, the abundances of these deep-dweller species are increased (Ravelo and Fairbanks, 1992; Ravelo et al., 1990). Overall, the CSH1 DOT estimates show rapid decreases during most of the cooling episodes since $88 \mathrm{ka}$ (Fig. 7), such decreasing DOT which indicate a lowering of surface water heat content by a southward 
movement of cold subarctic water mass, weakening of the Kuroshio or stronger winter AM.

\section{Discussion}

\subsection{Multiproxy hydrographic reconstructions}

The most noticeable hydrographic changes are revealed by the faunal analysis. Our faunal Factor 1, which represents the most dominant species G. bulloides in CSH1 (Table 2), serves as a proxy for local upwelling and may also indicate the changes in productivity (Anderson and Prell, 1993; Emeis et al., 1995; Peeters et al., 2002). In surface sediments in the northern OT, the abundances of G. bulloides are high in the ECS shelves and mainly related to lower SSS and highnutrient water with an average abundance of $12 \%$ (Xu and Oda, 1999). In the marginal seas of the northwestern Pacific, higher abundances of G. bulloides are mainly associated with upwelling (Ijiri et al., 2005; Xiang et al., 2007). High Factor 1 scores and G. bulloides abundances during the late MIS 3 (Figs. 5 and 8a) may be linked to strong upwelling with an increased nutrient supply that triggers high productivity.

The faunal Factor 2 represents warm-water species $G$. ruber, G. glutinata and P. obliquiloculata (Table 2), serving as a better proxy for Kuroshio intrusion into the OT that further regulates the strength of the TWC. The same modern planktonic foraminera assemblages can also be found in the surface sediments of the OT and Ryukyu Arc region, which is closed related to the Kuroshio (Thompson, 1981; Ujiie and Ujiie, 2000).We could thus infer that the higher scores of Factor 2 during MIS 5.1 and MIS 1 (Fig. 8b) reflect a stronger Kuroshio intrusion into the northern OT.

The faunal Factor 3 includes cold-water species N. pachyderma (dex.) and G. quinqueloba, higher scores of which indicate increased influence of cold water entering the northern OT. N. pachyderma (dex.) and G. quinqueloba mainly live in arctic and subarctic waters. In the modern surface sediments of the ECS, however, the abundances of $N$. pachyderma are very low (Xu and Oda, 1999). From 12.5 to $24 \mathrm{ka}$, the higher Factor 3 scores and abundances of N. pachyderma (dex.) (Figs. 5 and 8c) along with low-alkenone SST (Fig. 7) indicate a strong invasion of cold water, which is related to the southward shift of the subarctic front and an abrupt northward shift of the front by $12 \mathrm{ka}$. The higher abundances of $G$. quinqueloba in the surface sediments of the ECS are mainly limited in the Yangtze Estuary region with low SSS and SST, indicating the influence of cold, low-salinity coastal water masses (Xu and Oda, 1999). High abundances of G. quinqueloba are linked to low SSS before $18 \mathrm{ka}$, the late MIS 3 and the early MIS 4 (Fig. 7b and c), indicating an increased river runoff effect or increased precipitation versus evaporation in the northern OT while the sea level was relatively lower. During the LGM and $\mathrm{H}$ events/stadials, the decreased abundances of $G$. quinqueloba correspond well to the in-

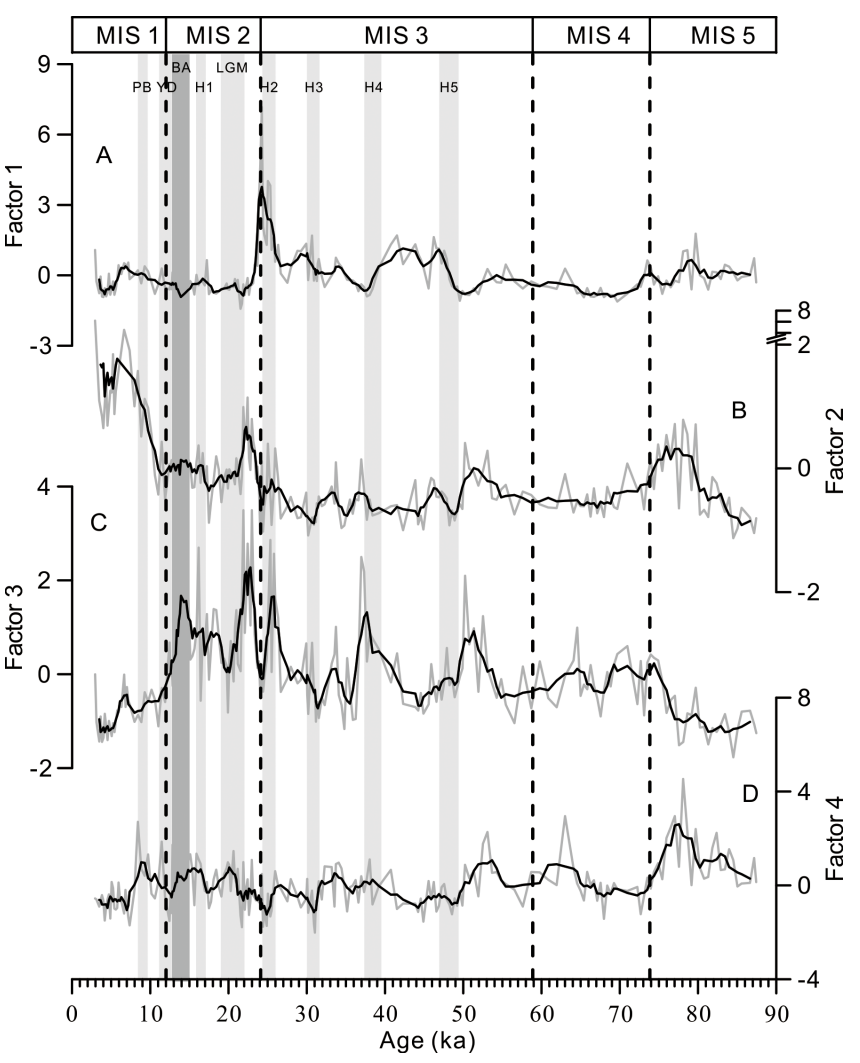

Figure 8. Time series plots of the four main factor scores for planktonic foraminiferal assemblages. Gray bars are the same as those in Fig. 4.

creased SSS, which reflects stronger winter and/or weaker summer AMs.

Factor 4 is mainly composed of the species related to the DOT, including G. inflata and N. Dutertrei (Hemleben et al., 1989). In the regions of the Kuroshio and the Taiwan Warm Current, the abundances of $N$. dutertrei in modern surface sediments are as high as 20-40\% (Wang et al., 1988). In the ECS and the northern OT, the high abundances of $N$. dutertrei in the surface sediments appear to be associated with transitional zones between the Kuroshio and coastal water ( $\mathrm{Li}$ et al., 2007). In CSH1, high abundances of $N$. dutertrei correlate well with the shallower DOT (Fig. 7), suggesting that the Factor 4 scores and $N$. dutertrei abundances are indicative of nutrient and upwelling conditions. Though $G$. inflata is also a species indicative of strong mixing (Thompson, 1981), in core CSH1, its abundances show no correlation with the DOT (Fig. 7). We consider that the abundances of G. inflata may respond to nutrient distributions (Cléroux et al., 2007), or more extreme or short-lived upwelling conditions that are not well captured by the DOT transfer function used in this study.

Our approach of combined $\delta^{18} \mathrm{O}_{\text {ruber }}$ and alkenone SST for deconvoluting SSS (Fig. 7a and b) indicates a modern value since $\sim 8 \mathrm{ka}$, confirming the reliability of this estimation 
method. The local SSS in the northern OT is mainly regulated by two factors - river runoff and oceanic high-salinity water brought by the Kuroshio. The effects of both factors are constrained by the sea level. In addition, the upwelling may also bring saline water to the surface. In our CSH1 SSS record, the SSS values are $\sim 2$ times higher than that of today during MIS 5.1, while the SST difference between MIS 1 and MIS 5.1 is $\sim 0.3^{\circ} \mathrm{C}$, which translates to only $\sim 0.066 \%$ o as a temperature effect in driving $\delta^{18} \mathrm{O}_{\text {ruber }}$ changes. However, the $\delta^{18} \mathrm{O}_{\text {ruber }}$ difference between MIS 1 and MIS 5.1 is $\sim 0.74 \%$, which cannot be affected by temperature change. Therefore, this observation suggests that the much heavier $\delta^{18} \mathrm{O}_{\text {ruber }}$ in MIS 5.1 and the whole CSH1 $\delta^{18} \mathrm{O}_{\text {ruber }}$ record must be dominated by other factors, such as local SSS and regional precipitation versus evaporation.

This estimation, along with the higher abundances of P.obliquiloculata (Fig. 5), suggests stronger intrusion of the Kuroshio into the northern OT. During the conditions of lower sea levels, the saline Kuroshio water intrusions were weakened. As seen from the faunal records in the late MIS 3 (Fig. 5), the increased CSH1 SSS values coincide with higher abundances of G. bulloides and Factor 1, which are strong indications of strong upwelling in the northern OT ( $\mathrm{Li}$ et al., 2007). After $16 \mathrm{ka}$, though the global sea level has risen, the saline intrusion of the Kuroshio might be counteracted by fresh river runoff water from increased regional precipitation brought by intensified summer AM (Wang et al., 2001, 2008; Yuan et al., 2004), resulting in low-SSS conditions since then (Fig. 7b). During the LGM and $\mathrm{H}$ events/stadials, the SSS values were significantly increased (Fig. 7b). The $\delta^{18} \mathrm{O}$ of stalagmites in East China showed weakened summer AM at the time (Wang et al., 2001, 2008; Yuan et al., 2004), causing regional aridity and less precipitation/river runoff from the Yangtze and Huanghe rivers (Fig. 9), which are responsible for the high-saline water in the northern OT. In addition, the stronger winter AM during the cold episodes may have intensified the surface water mixing, which also helps increase the SSS.

Evidence from our CSH1 SSTs, SSSs, DOTs and $P$. obliquiloculata abundances support the idea that the strength of the Kuroshio and the TWC has been responding to regional and global climate forcing for the last $88 \mathrm{ka}$. The responses of the Kuroshio to climate are exemplified in the lower SST, SSS, shallower DOT and lower abundances of $P$. Obliquiloculata (Fig. 9), which imply weakened Kuroshio intrusion into the northern OT during the LGM. During MIS 1 and MIS 5.1, evidence of higher SST, SSS and higher abundances of $P$. obliquiloculata (Fig. 9) indicate strong Kuroshio intrusion. Low-sea-level conditions appear to block or decrease the intrusion of the Kuroshio into the OT. It is exemplified by the lower SST and lower abundances of $P$. obliquiloculata during MIS 3 and MIS 4 when compared to MIS 1 and MIS 5.1. Our records show consistent evidence provided from core MD982195 (Ijiri et al., 2005) (Fig. 1), indicating that it is a robust regional pattern in the north- ern OT. Previous studies also suggest that the strength of the Kuroshio was weakened abruptly during the late Holocene (Jian et al., 2000a; Li et al., 1997; Shieh et al., 1997), a mysterious short-lived episode that may imply a weakened Kuroshio. It was possible to find this event in CSH1 (Fig. 5), suggesting that it is also a robust regional feature with a greater spatial scale in the main Kuroshio region. Despite disagreement between studies using paleoceanographic data and modeling approaches on whether or not the Kuroshio entered the OT during glacial low-sea-level conditions (Lee et al., 2013; Ujiié and Ujiié, 1999), our evidence shows that the high-SST and -SSS conditions and Kuroshio-indicative planktonic foraminifera existed in at least one major branch of the Kuroshio in the northern OT. Though the volume transport of the Kuroshio responds to the trade wind (Sawada and Handa, 1998), which may cause regional variability of Kuroshio intrusion into the OT, our multiproxy records show homogenous responses in the OT and suggest that the Kuroshio is the most dominant mechanism governing the hydrographic variations over the past $88 \mathrm{ka}$.

\subsection{Millennial-scale responses of the Kuroshio}

Our multiproxy hydrographic records present clear evidence for high-frequency, millennial-scale fluctuations in the responses of the Kuroshio. The high-frequency component in CSH1 $\delta^{18} \mathrm{O}_{\text {ruber }}$ shares similar features with foraminifer $\delta^{18} \mathrm{O}$ in MD982195 (Ijiri et al., 2005) and GISP2 ice core $\delta^{18} \mathrm{O}$ (Stuiver and Grootes, 2000). Our CSH1 alkenone SST shows abrupt decreases and 3.5, 2.1, 1.5, 1.4 and $1.7^{\circ} \mathrm{C}$ lower than modern values during the short-term intervals of 15.8-17.1, 24.3-26, 29.9-31.6, 37.3-39.5 and 46.9$49.4 \mathrm{ka}$, respectively (Fig. 7a). Moreover, the average values of $\delta^{18} \mathrm{O}_{\text {ruber }}$ during those periods are relatively heavier by $1.43,1.65,1.48,1.59$ and $1.15 \%$, respectively, than that in the most recent cooling at $\sim 8 \mathrm{ka}(-2.12 \%$ o). The timing of the heavier events corresponds to the $\mathrm{H}$ events/stadial (Bond et al., 1992, 1999). From 12.8 to $15 \mathrm{ka}$, the increased SST and lighter $\delta^{18} \mathrm{O}_{\text {ruber }}$ in CSH1 correspond well with the BøllingAllerød warm period. During $\mathrm{H}$ events/stadials, the abundances of $N$. pachyderma increased, while the warm-water species G. ruber and G. sacculifer decreased (Fig. 5). Similar millennial-scale hydrographic responses have been reported from marine core studies in the whole OT and stalagmite AM records from East China (Li et al., 2001; Wang et al., 2008) (Fig. 9). Taking all evidence together, we conclude that the millennial-scale oscillations represent one of the robust, common responses in Kuroshio and AM-dominant regions, and several mechanisms that invoke the teleconnection between the AM and the North Atlantic via the westerlies have been suggested previously (Nagashima et al., 2011; Porter and An, 1995). 


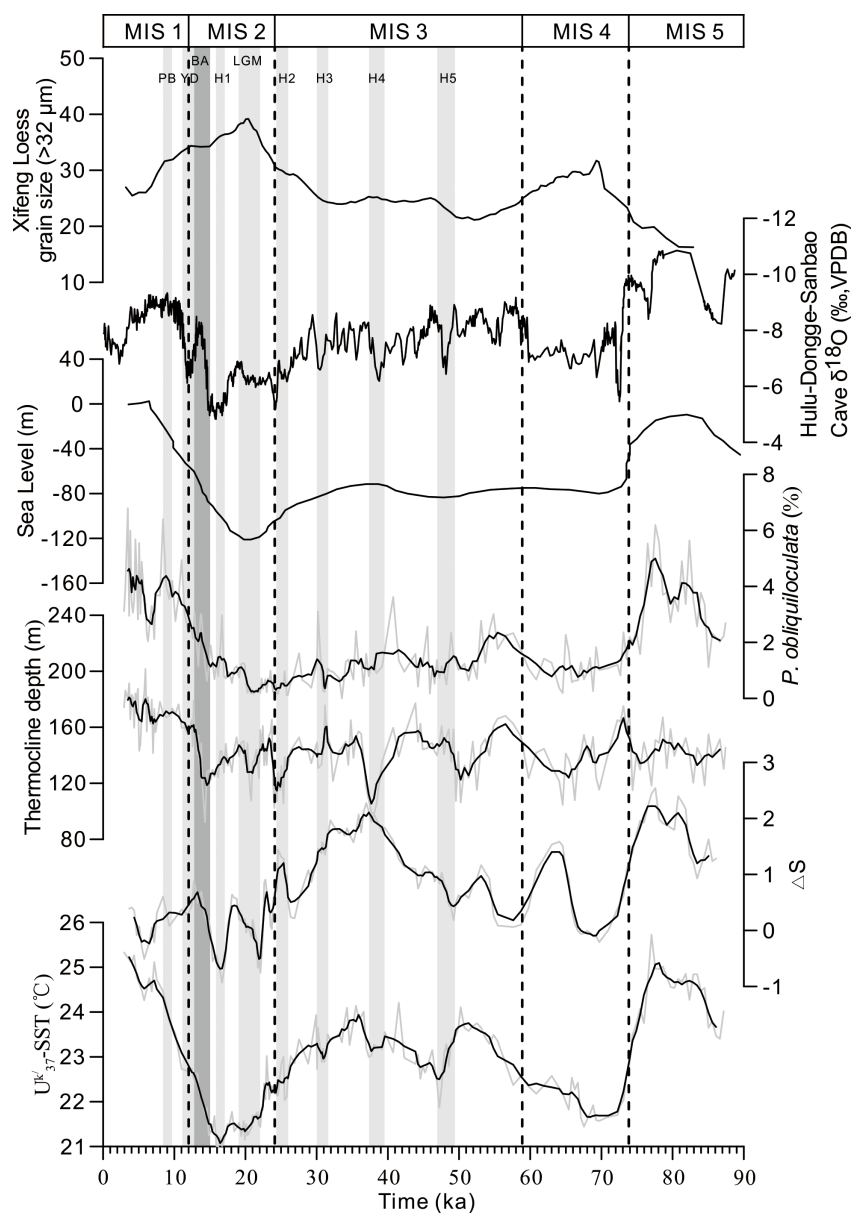

Figure 9. Time series plots of temperature, salinity, depth of the thermocline and the contents of $P$. obliquiloculata, compared to sea level (Cutler et al., 2003); $\delta^{18} \mathrm{O}$ curve of cave stalagmite from East China (Wang et al., 2001, 2008; Yuan et al., 2004); grain size of Xifeng loess (Guo et al., 2009). Gray bars are the same as those in Fig. 4.

\subsection{Orbital-scale responses of the Kuroshio}

Precession forcing that changes the seasonal distributions of incoming solar insolation is a well-known factor in driving past monsoon variability. In core $\mathrm{CSH} 1$, the spectral analysis of $\delta^{18} \mathrm{O}_{\text {ruber }}$, SST, SSS and DOT and the abundances of $G$. ruber, P. obliquiloculata and N. pachyderma (dex.) all show a common frequency during the precession cycles (near $24 \mathrm{ka}$, Fig. 10), indicating that precession forcing plays an important role in regulating the hydrographic changes in the northern OT.

Though the orbital-scale Kuroshio responses to the AM were identified in our spectral analysis of the hydrographic records, the controlling mechanisms of Kuroshio hydrographies are much more complicated than the mechanism interpreted solely on the basis of an AM mechanism. For example, both SST and SSS values were high during MIS 5.1
(Fig. 7). The average SST was close to the modern longterm instrumental observation value but the SSS was $\sim 1.6$ higher than today. While the summer AM is considered stronger during this specific episode, the high SSS and low abundances of the coastal-water species (Fig. 7) G. quinqueloba suggest a reduced river runoff, which conflicts with the condition of higher precipitation by enhanced summer AM. Moreover, during MIS 5.1, higher abundances of $P$. obliquiloculata suggest stronger Kuroshio (Fig. 5). In this context, we consider that the Kuroshio climate in MIS 5.1 is warm but dry, which is detectable from the other episodes in the western Pacific and East Asian paleoclimate (Ikehara and Oshima, 2009; Morley et al., 1991; Sun et al., 2003).

During MIS 4, the sea level fell and brought the CSH1 site closer to the coastline (Cutler et al., 2003) (Fig. 9). Increased river runoff caused decreased SSS values and increased abundances of the coastal-water species G. quinqueloba during this time interval, while the abundances of $P$. obliquiloculata remained low, indicating a weakened Kuroshio intrusion. In particular, during MIS 4, the abundances of G. quinqueloba decreased, corresponding well with the increased SSS. The Chinese loess grain size $(>32 \mu \mathrm{m})$ indicates that the winter AM intensified during MIS 4.2 (Guo et al., 2009) (Fig. 9) and echoed the scenario reconstructed here. In addition, during MIS 4 the higher abundances of $N$. pachyderma indicate a southward migration of subarctic water, suggesting coherent atmospheric and oceanic changes in response to northern hemispheric cooling.

Our alkenone SST and SSS reached maxima during the early MIS $3(\sim 50 \mathrm{ka})$ and mid-MIS $3(\sim 35 \mathrm{ka})$ and rapidly decreased from $\sim 35 \mathrm{ka}$ onwards (Fig. 9). However, lower abundances of $P$. obliquiloculata during MIS 3 suggest a weakened Kuroshio intrusion (Fig. 9), which may have been caused by a partial blocking of gateways into the OT with relatively low sea levels during this time. The MIS 3 climate was interrupted by several millennial-scale, high-abundance episodes of $N$. pachyderma and G. inflata, indicating rapid cooling of surface seawater (Fig. 5). The increased abundances of the upwelling species $G$. bulloides and Factor 1 scores (Figs. 5 and 8) suggest that the MIS 3 climate was characterized by a strengthened winter AM, with more frequent southward shifting of the subarctic front and weakened Kuroshio intrusion into the northern OT mainly due to lower sea levels.

During MIS 2, high abundances of $N$. pachyderma (dex.) suggest a southward shift of the subarctic frontal zone, resulting in low-alkenone SST and SSS (Fig. 7a and b). The DOT was much shallower, an indication of the reduced heat content in the surface water of the Kuroshio in the northern OT. After $16 \mathrm{ka}$, the abundances of $P$. obliquiloculata together with other warm-water species, such as $G$. ruber, gradually increased with the rise in sea level, indicating an intensified Kuroshio intrusion. During the LGM and H1, while the northern hemispheric climate was very cold, our CSH1 SST and SSS both decreased. This combination of hydrographic 

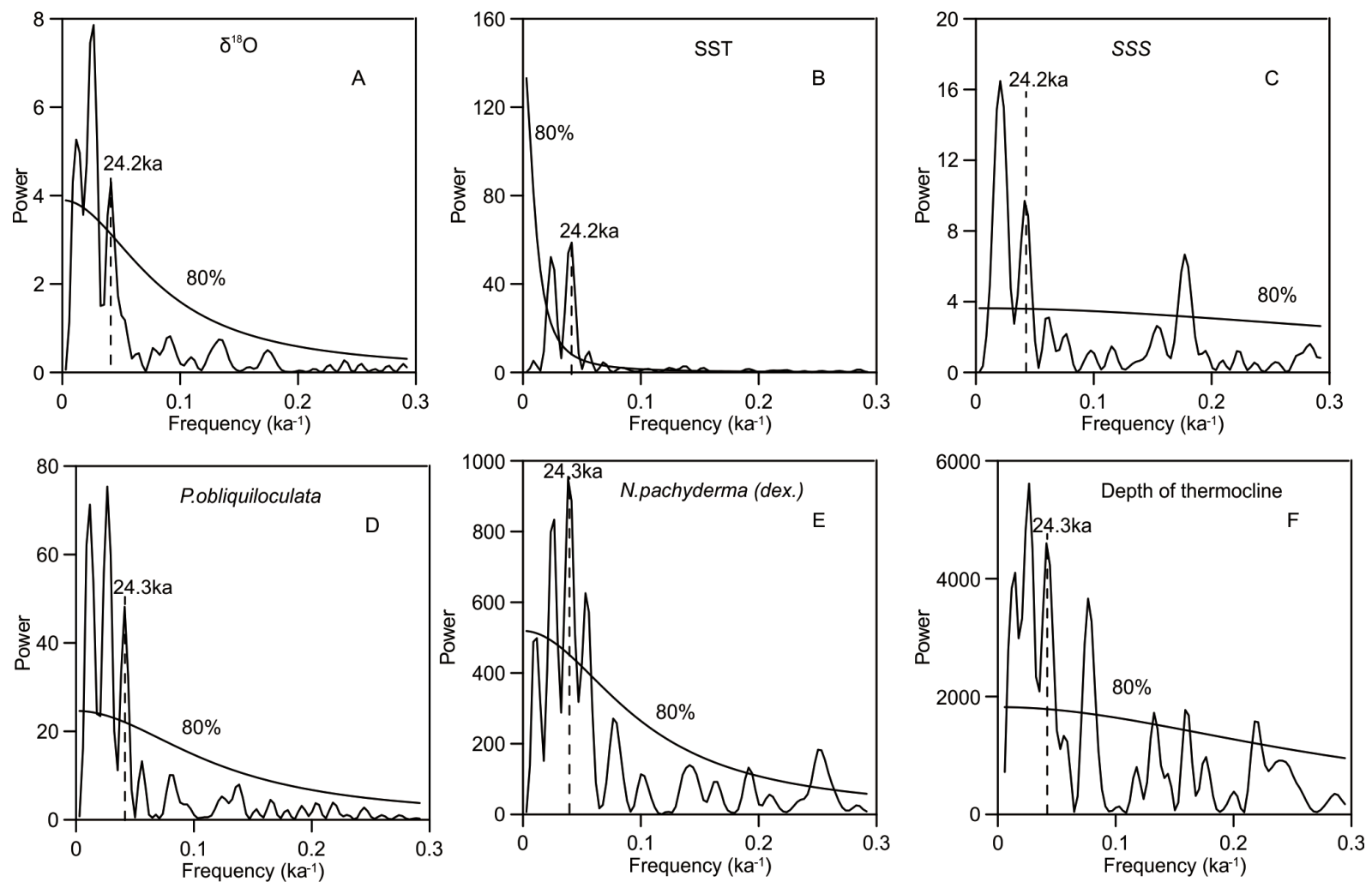

Figure 10. Power spectrum of the $\delta^{18} \mathrm{O}$, SST (sea surface temperature), SSS (sea surface salinity), depth of the thermocline and the abundances of P.obliquiloculata and N.pachyderma (dex.) time series. All proxies show a common frequency during the precession cycles (near $24 \mathrm{ka})$.

conditions indicates a weakened Kuroshio, which may have been diverted into the open northwestern Pacific at lower latitudes. The hydrographic conditions during the LGM and H1 appear to not be well explained by the AM, as weakened summer AM at these cold intervals would cause low SST and high SSS, which are inconsistent with our reconstructions.

Since $12 \mathrm{ka}$, while the global climate has continued to be much warmer, our SST values have increased, responding to the rise in sea level and stronger intrusion of the Kuroshio into the northern OT. The stronger Kuroshio in response to rising sea levels is evidenced by higher abundances of warm-water species and of $P$. obliquiloculata. The lower abundances of $G$. quinqueloba indicate a reduced influence of coastal water since $12 \mathrm{ka}$. The abundances of $N$. pachyderma (dex) decreased abruptly, indicating a rapid northward shift of the subarctic frontal zone. Therefore, our reconstruction supports the idea that the Kuroshio is the main factor that controlling the hydrographic evolution in the northern OT since $12 \mathrm{ka}$.

\section{Conclusions}

Based on AMS ${ }^{14} \mathrm{C}$ and $\delta^{18} \mathrm{O}$ correlation, a new highresolution hydrographic record was first established with an extension down to $88 \mathrm{ka}$ in the northern OT. Multiproxies, including alkenone SST, $\delta^{18} \mathrm{O}$ deconvoluted SSS, planktonic foraminiferal assemblages and the DOT from core CSH1, suggest that the hydrography of the surface water in the OT is a homogenous system that has responded dramatically mainly to the global sea level, the Kuroshio, AM and subarctic front. The main conclusions are as following:

1. The surface hydrologic variability in the northern OT of the past $88 \mathrm{ka}$ shows sensitive responses to the abrupt climate changes. During MIS 1 and MIS 5.1, the surface hydrology was dominated by the Kuroshio while the sea level was relatively high. During MIS 2, 3 and 4, however, stronger winter AM and a southward mean position of the subarctic front played more important roles in governing the hydrographic conditions.

2. On millennial timescales, five abrupt events with decreased SSTs and increased SSS corresponding to the timing of Heinrich events were identified in CSH1 hydrographic records. We identified these abrupt events as responses to relatively weaker summer AM which may be linked to a close teleconnection between the AM and the North Atlantic via the changes in the strength of the westerlies. 
3. All proxies show a common frequency near the precession cycles, suggesting an important monsooncontrolled mechanism in the surface water in the OT. During MIS 5.1, the ocean climate in the northern OT was warm but dry, which was detectable from the other episodes in the western Pacific and the East Asian paleoclimate. During MIS 4 and MIS 2, the ocean climate was dry and cold, which is thought to be mainly due to stronger winter AM and southward shifts of the subarctic front. During MIS 3, the ocean climate was characterized by a strengthened summer AM but interrupted by millennial-scale cooling events, indicating a rapid latitudinal shifting of the subarctic front and weakened Kuroshio intrusion into the northern OT. During MIS 1, the Kuroshio returned as a main factor controlling the hydrographic evolution in the northern OT.

Acknowledgements. This study was supported by the National Natural Science Foundation of China (Grant no. 40710069004, 40431002, 41206059, 41221004), by the Basic Scientific Fund for National Public Research Institutes of China (no. 2012G31, GY0213G23) and by the Youth Foundation of the State Oceanic Administration People's Republic of China (2012301). We thank Yoshiki Saito (Geological survey of Japan) for helping to determine the reflectance of volcanic glass. We also thank Min-Te Chen (Taiwan Ocean University) and two anonymous reviewers for providing insightful comments and suggestions, which greatly improved the quality of the paper.

Edited by: M.-T. Chen

\section{References}

Anderson, D. M. and Prell, W. L.: A 300 Kyr Record of Upwelling Off Oman during the Late Quaternary: Evidence of the Asian Southwest Monsoon, Paleoceanography, 8, 193-208, 1993.

Andreasen, D. J. and Ravelo, A. C.: Tropical Pacific Ocean thermocline depth reconstructions for the Last Glacial Maximum, Paleoceanography, 12, 395-413, 1997.

Bintanja, R., van de Wal, R. S. W., and Oerlemans, J.: Modelled atmospheric temperatures and global sea levels over the past million years, Nature, 437, 125-128, 2005.

Bond, G., Heinrich, H., Broecker, W., Labeyrie, L., McManus, J., Andrews, J., Huon, S., Jantschik, R., Clasen, S., and Simet, C.: Evidence for massive discharges of icebergs into the North Atlantic ocean during the last glacial period, Nature, 360, 245-249, 1992.

Bond, G. C., Showers, W., Elliot, M., Evans, M., Lotti, R., Hajdas, I., Bonani, G., and Johnson, S.: The North Atlantic's 1-2 Kyr Climate Rhythm: Relation to Heinrich Events, Dansgaard/Oeschger Cycles and the Little Ice Age, in: Mechanisms of Global Climate Change at Millennial Time Scales, edited by: Clark, P. U., Webb, R. S., and Keigwin, L. D., American Geophysical Union, 35-58, 1999.
Buhring, C.: East Asian Monsoon variability on orbital- and millennial-to-sub-decadal time scales, Ph.D thesis, University of Kiel, 164 pp., 2001.

Chang, Y.-P., Wang, W. L., Yokoyama, Y., Matsuzaki, H., Kawahata, H., and Chen, M. T.: Millennial-scale planktic foraminifer faunal variability in the East China Sea during the past 40000 years (IMAGES MD012404 from the Okinawa Trough), Terr Atmos. Oc. Sci., 19, 389-401, 2008.

Chang, Y.-P., Wang, W.-L., and Chen, M.-T.: The last 100000 years' palaeoenvironmental changes inferred from the diatom assemblages of core MD012404 from the Okinawa Trough, East China Sea, J. Quat. Sci., 24, 890-901, 2009.

Chen, J., Zhang, D., Zhang, W., and Li, T.: The paleoclimatic change since the last galciation in the north of Okinawa Trough based on the spore-pollen records, Acta Oceanologica Sinica, 28, 85-91, 2006 (in Chinese with English Abstract).

Chen, M.-T., Shiau, L.-J., Yu, P.-S., Chiu, T.-C., Chen, Y.-G., and Wei, K.-Y.: $500000-$ Year records of carbonate, organic carbon, and foraminiferal sea-surface temperature from the southeastern South China Sea (near Palawan Island), Palaeogeography, Palaeoclimatology, Palaeoecology, 197, 113-131, 2003.

Cléroux, C., Cortijo, E., Duplessy, J.-C., and Zahn, R.: Deep-dwelling foraminifera as thermocline temperature recorders, Geochemistry, Geophysics, Geosystems, 8, Q04N11, doi:10.1029/2006GC001474, 2007.

Coplen, T. B.: Calibration of the calcite-water oxygen-isotope geothermometer at Devils Hole, Nevada, a natural laboratory, Geochimica et Cosmochimica Acta, 71, 3948-3957, 2007.

Cutler, K. B., Edwards, R. L., Taylor, F. W., Cheng, H., Adkins, J., Gallup, C. D., Cutler, P. M., Burr, G. S., and Bloom, A. L.: Rapid sea-level fall and deep-ocean temperature change since the last interglacial period, Earth Planet. Sci. Lett., 206, 253-271, 2003.

Du, J.-Q., Chen, M., Cao, J.-P., Qiu, Y.-S., Tong, J.-L., Ma, Q., and Yang, J.-H.: Oxygen isotope in seawater and its hydrological implication in the southern Yellow Sea and the East China Sea, Oceanologia et Limnoloia Sinica, 43, 1057-1066, 2012 (in Chinese with English Abstract).

Emeis, K.-C., Anderson, D. M., Doose, H., Kroon, D., and SchulzBull, D.: Sea-Surface Temperatures and the History of Monsoon Upwelling in the Northwest Arabian Sea during the Last 500000 Years, Quat. Res., 43, 355-361, 1995.

Ge, S., Shi, X., Wu, Y., Lee, T., Xiong, Y., and Saito, Y.: Rock magnetic property of gravity core CSH1 from the northern Okinawa Trough and the effect of early diagenesis, Ac. Oceanol. Sinica, 26, 54-65, 2007.

Guo, Z. T., Berger, A., Yin, Q. Z., and Qin, L.: Strong asymmetry of hemispheric climates during MIS-13 inferred from correlating China loess and Antarctica ice records, Clim. Past, 5, 21-31, doi:10.5194/cp-5-21-2009, 2009.

Hemleben, C., Spindler, M., and Anderson, O. R.: Modern planktonic foraminifera, Springer, Berlin, 1989.

Hsueh, Y.: The Kuroshio in the East China Sea, J. Mar. Syst., 24, 131-139, 2000.

Hsueh, Y., Wang, J., and Chern, C. S.: The Intrusion of the Kuroshio across the continental-shelf northeast of Taiwan, J. Geophys. Res.-Oc., 97, 14323-14330, 1992.

Ijiri, A., Wang, L. J., Oba, T., Kawahata, H., and Huang, C. Y.: Paleoenvironmental changes in the northern area of the East 
China Sea during the past 42000 years, Palaeogeogr. Palaeoclim. Palaeoecol., 219, 239-261, 2005.

Ikehara, K. and Oshima, H.: Orbital- and millennial-scale fluctuations in late Quaternary marine pollen records from the Japan Sea, J. Quat. Sci., 24, 866-879, 2009.

Jian, Z. M., Saito, Y., Wang, P. X., Li, B. H., and Chen, R. H.: Shifts of the Kuroshio axis over the last 20000 years, Chinese Science Bulletin, 43, 1053-1056, 1998.

Jian, Z., Wang, P., Saito, Y., Wang, J., Pflaumann, U., Oba, T., and Cheng, X.: Holocene variability of the Kuroshio Current in the Okinawa Trough, northwestern Pacific Ocean, Earth Planet. Sci. Lett., 184, 305-319, 2000a.

Jian, Z. M., Li, B. H., Huang, B. Q., and Wang, J. L.: Globorotalia truncatulinoides as indicator of upper-ocean thermal structure during the Quaternary: evidence from the South China Sea and Okinawa Trough, Palaeogeogr. Palaeoclim. Palaeoecol., 162, 287-298, 2000b.

JODC Data On-line Service System, available at: http://www.jodc. go.jp/service.htm, last access: 16 November 2013.

Kao, S. J., Roberts, A. P., Hsu, S. C., Chang, Y. P., Lyons, W. B., and Chen, M. T.: Monsoon forcing, hydrodynamics of the Kuroshio Current, and tectonic effects on sedimentary carbon and sulfur cycling in the Okinawa Trough since $90 \mathrm{ka}$, Geophys. Res. Lett., 33, L05610, doi:10.1029/2005gl025154, 2006a.

Kao, S. J., Wu, C.-R., Hsin, Y.-C., and Dai, M.: Effects of sea level change on the upstream Kuroshio Current through the Okinawa Trough, Geophys. Res. Lett., 33, L16604, doi:10.11029/12006gl026822, 2006b.

Kawahata, H., Nohara, M., Aoki, K., Minoshima, K., and Gupta, L. P.: Biogenic and abiogenic sedimentation in the northern East China Sea in response to sea-level change during the Late Pleistocene, Glob. Planet. Change, 53, 108-121, 2006.

Lee, C.-S., Shor Jr, G. G., Bibee, L. D., Lu, R. S., and Hilde, T. W. C.: Okinawa Trough: Origin of a back-arc basin, Mar. Geo., 35, 219-241, 1980

Lee, K. E., Lee, H. J., Park, J.-H., Chang, Y.-P., Ikehara, K., Itaki, T., and Kwon, H. K.: Stability of the Kuroshio path with respect to glacial sea level lowering, Geophys. Res. Lett., 40, 392-396, 2013

Li, B. H., Jian, Z. M., and Wang, P. X.: Pulleniatina obliquiloculata as a paleoceanographic indicator in the southern Okinawa Trough during the last 20000 years, Mar. Micropal., 32, 59-69, 1997.

Li, T., Liu, Z., Hall, M. A., Saito, Y., Berne, S., Cang, S., and Cheng, Z.: A broad deglacial $\delta 13 \mathrm{C}$ minimum event in planktonic foraminiferal records in the Okinawa Trough, Chinese Sci. Bull., 47, 599-603, 2002

Li, T. G., Liu, Z. X., Hall, M. A., Berne, S., Saito, Y., Cang, S. X., and Cheng, Z. B.: Heinrich event imprints in the Okinawa Trough: evidence from oxygen isotope and planktonic foraminifera, Palaeogeogr. Palaeoclim. Palaeoecol., 176, 133146, 2001

Li, T. G., Sun, R. T., Zhang, D. Y., Liu, Z. X., Li, Q., and Jiang, B.: Evolution and variation of the Tsushima warm current during the late Quaternary: Evidence from planktonic foraminifera, oxygen and carbon isotopes, Sci. China Ser. D-Earth Sci., 50, 725-735, 2007.
Lie, H.-J. and Cho, C.-H.: Recent advances in understanding the circulation and hydrography of the East China Sea, Fish. Oceanogr., 11, 318-328, 2002.

Lie, H. J., Cho, C. H., Lee, J. H., and Lee, S.: Structure and eastward extension of the Changjiang River plume in the East China Sea, J. Geophys. Res. Oc., 108, 3077, doi:10.1029/2001JC001194, 2003.

Liu, Z. X., Li, T. G., Li, P. Y., Huang, Q. Y., Berne, S., Saito, Y., Cheng, Z. B., Wei, G. J., Liu, L. J., and Li, Z.: The paleoclimatic events and cause in the Okinawa Trough during $50 \mathrm{kaBP}$, Chinese Sci. Bull., 46, 153-157, 2001.

Machida, H.: The stratigraphy, chronology and distribution of distal marker-tephras in and around Japan, Glob. Planet. Change, 21, 71-94, 1999.

Martinson, D. G., Pisias, N. G., Hays, J. D., Imbrie, J., Moore, T. C., and Shackleton, N. J.: Age dating and the orbital theory of the ice ages: Development of a high-resolution 0 to 300 000-year chronostratigraphy, Quat. Res., 27, 1-29, 1987.

Morley, J. J., Heusser, L. E., and Shackleton, N. J.: Late Pleistocene/Holocene radiolarian and pollen records from sediments in the Sea of Okhotsk, Paleoceanography, 6, 121-131, 1991.

Mulitza, S., Arz, H., Kemle-von Mücke, S., Moos, C., Niebler, H. S., Pätzold, J., and Segl, M.: The South Atlantic Carbon Isotope Record of Planktic Foraminifera, in: Use of Proxies in Paleoceanography, edited by: Fischer, G. and Wefer, G., Springer Berlin Heidelberg, 427-445, 1999.

Mulitza, S., Donner, B., Fischer, G., Paul, A., Pätzold, J., Rühlemann, C., and Segl, M.: The South Atlantic Oxygen Isotope Record of Planktic Foraminifera, in: The South Atlantic in the Late Quaternary, edited by: Wefer, G., Mulitza, S., and Ratmeyer, V., Springer Berlin Heidelberg, 121-142, 2004.

Muller, P. J., Kirst, G., Ruhland, G., von Storch, I., and RosellMele, A.: Calibration of the alkenone paleotemperature index $\mathrm{U}_{37}^{K^{\prime}}$ based on core-tops from the eastern South Atlantic and the global ocean $\left(60^{\circ} \mathrm{N}-60^{\circ} \mathrm{S}\right)$, Geochimica et Cosmochimica Acta, 62, 1757-1772, 1998 .

Nagashima, K., Tada, R., Tani, A., Sun, Y., Isozaki, Y., Toyoda, S., and Hasegawa, H.: Millennial-scale oscillations of the westerly jet path during the last glacial period, J. As. Earth Sci., 40, 1214 1220, 2011.

Nakanishi, T., Yamamoto, M., Irino, T., and Tada, R.: Distribution of glycerol dialkyl glycerol tetraethers, alkenones and polyunsaturated fatty acids in suspended particulate organic matter in the East China Sea, J. Oceanogr., 68, 959-970, 2012.

Oba, T.: Paleoceanographic information obtained by the isotopic measurement of individual foraminiferal specimens, Proceedings of the First International Conference Asian Marine Geology, Shanghai, 1988, 169-180, 1988.

Peeters, F. J. C., Brummer, G.-J. A., and Ganssen, G.: The effect of upwelling on the distribution and stable isotope composition of Globigerina bulloides and Globigerinoides ruber (planktic foraminifera) in modern surface waters of the NW Arabian Sea, Glob. Planet. Change, 34, 269-291, 2002.

Pflaumann, U., Duprat, J., Pujol, C., and Labeyrie, L. D.: SIMMAX: A modern analog technique to deduce Atlantic sea surface temperatures from planktonic foraminifera in deep-sea sediments, Paleoceanography, 11, 15-35, 1996.

Pflaumann, U. and Jian, Z.: Modern distribution patterns of planktonic foraminifera in the South China Sea and western Pacific: a 
new transfer technique to estimate regional sea-surface temperatures, Mar. Geol., 156, 41-83, 1999.

Porter, S. C. and An, Z.: Correlation between climate events in the North Atlantic and China during the last glaciation, Nature, 375, 305-308, 1995.

Ravelo, A. C. and Fairbanks, R. G.: Oxygen Isotopic Composition of Multiple Species of Planktonic Foraminifera: Recorders of the Modern Photic Zone Temperature Gradient, Paleoceanography, 7, 815-831, 1992.

Ravelo, A. C., Fairbanks, R. G., and Philander, S. G. H.: Reconstructing tropical Atlantic hydrography using planktontic foraminifera and an ocean model, Paleoceanography, 5, 409431, 1990

Reimer, P. J., Baillie, M. G. L., Bard, E., Bayliss, A., Beck, J. W., Blackwell, P. G., Ramsey, C. B., Buck, C. E., Burr, G. S., Edwards, R. L., Friedrich, M., Grootes, P. M., Guilderson, T. P., Hajdas, I., Heaton, T. J., Hogg, A. G., Hughen, K. A., Kaiser, K. F., Kromer, B., McCormac, F. G., Manning, S. W., Reimer, R. W., Richards, D. A., Southon, J. R., Talamo, S., Turney, C. S. M., van der Plicht, J., and Weyhenmeye, C. E.: Intcal09 and Marine09 Radiocarbon age calibration curves, 0-50000 years Cal BP, Radiocarbon, 51, 1111-1150, 2009.

Sawada, K. and Handa, N.: Variability of the path of the Kuroshio ocean current over the past 25000 years, Nature, 392, 592-595, 1998.

Shieh, Y. T., Wang, C. H., Chen, M. P., and Yung, Y. L.: The Last Glacial Maximum to Holocene environment changes in the southern Okinawa Trough, J. As. Earth Sci., 15, 3-8, 1997.

Sibuet, J. C., Letouzey, J., Barbier, F., Charvet, J., Foucher, J. P., Hilde, T. W. C., Kimura, M., Chiao, L.-Y., Marsset, B., Muller, C., and Stéphan, J. F.: Back Arc Extension in the Okinawa Trough, J. Geophys. Res. Sol. Earth, 92, 14041-14063, 1987.

Stuiver, M. and Grootes, P. M.: GISP2 Oxygen Isotope Ratios, Quat. Res., 53, 277-284, 2000.

Sun, X., Luo, Y., Huang, F., Tian, J., and Wang, P.: Deep-sea pollen from the South China Sea: Pleistocene indicators of East Asian monsoon, Mar. Geol., 201, 97-118, 2003.

Sun, Y. B., Oppo, D. W., Xiang, R., Liu, W. G., and Gao, S.: Last deglaciation in the Okinawa Trough: Subtropical northwest Pacific link to Northern Hemisphere and tropical climate, Paleoceanography, 20, PA4005, doi:10.1029/2004pa001061, 2005.

Tanaka, Y.: Coccolith fluxes and species assemblages at the shelf edge and in the Okinawa Trough of the East China Sea, DeepSea Res. Pt. II, 50, 503-511, 2003.

Thompson, P. R.: Planktonic foraminifera in the Western North Pacific during the past 150000 years: Comparison of modern and fossil assemblages, Palaeogeography, Palaeoclimatology, Palaeoecology, 35, 241-279, 1981.

Thunell, R. C., Curry, W. B., and Honjo, S.: Seasonal variation in the flux of planktonic foraminifera: time series sediment trap results from the Panama Basin, Earth Planet. Sci. Lett., 64, 44-55, 1983.
Ujiié, H. and Ujiié, Y.: Late Quaternary course changes of the Kuroshio Current in the Ryukyu Arc region, northwestern Pacific Ocean, Mar. Micropal., 37, 23-40, 1999.

Ujiie, Y. and Ujiie, H.: Distribution and oceanographic relationships of modern planktonic foraminifera in the Ryukyu arc region, northwest Pacific Ocean, J. Foramin. Res., 30, 336-360, 2000.

Wang, P. X., Zhang, J. J., and Zhao, Q. H.: Foraminifera and Ostracoda in sediments in the East China Sea, China Ocean Press, Beijing 1988 (in Chinese).

Wang, Y., Cheng, H., Edwards, R. L., An, Z., Wu, J., Shen, C.C., and Dorale, J. A.: A High-Resolution Absolute-Dated Late Pleistocene Monsoon Record from Hulu Cave, China, Science, 294, 2345-2348, 2001.

Wang, Y., Cheng, H., Edwards, R. L., Kong, X., Shao, X., Chen, S., Wu, J., Jiang, X., Wang, X., and An, Z.: Millennial- and orbitalscale changes in the East Asian monsoon over the past 224000 years, Nature, 451, 1090-1093, 2008.

Wu, Y., Cheng, Z., and Shi, X.: Stratigraphic and carbonate sediment characteristics of Core CSH1 from the northern Okinawa Trough, Adv. Marine Science, 22, 163-169, 2004 (in Chinese with English Abstract).

Xiang, R., Sun, Y. B., Li, T. G., Oppo, D. W., Chen, M. H., and Zheng, F.: Paleoenvironmental change in the middle Okinawa Trough since the last deglaciation: Evidence from the sedimentation rate and planktonic foraminiferal record, Palaeogeogr. Palaeoclim. Palaeoecol., 243, 378-393, 2007.

Xing, L., Zhao, M., Zhang, H., Liu, Y., and Shi, X.: Biomarker reconstruction of phytoplankton productivity and community structure changes in the middle Okinawa Trough during the last 15 ka, Chinese Sci. Bull., 53, 2552-2559, 2008.

$\mathrm{Xu}, \mathrm{X}$. D. and Oda, M.: Surface-water evolution of the eastern East China Sea during the last 36000 years, Mar. Geol., 156, 285304, 1999.

Yu, H., Liu, Z. X., Berne, S., Jia, G. D., Xiong, Y. Q., Dickens, G. R., Wei, G. J., Shi, X. F., Liu, J. P., and Chen, F. J.: Variations in temperature and salinity of the surface water above the middle Okinawa Trough during the past $37 \mathrm{kyr}$, Palaeogeogr. Palaeoclim. Palaeoecol., 281, 154-164, 2009.

Yuan, D., Cheng, H., Edwards, R. L., Dykoski, C. A., Kelly, M. J., Zhang, M., Qing, J., Lin, Y., Wang, Y., Wu, J., Dorale, J. A., An, Z., and Cai, Y.: Timing, Duration, and Transitions of the Last Interglacial Asian Monsoon, Science, 304, 575-578, 2004.

Zhang, J., Letolle, R., Martin, J. M., Jusserand, C., and Mouchel, J. M.: Stable oxygen isotope distribution in the Huanghe (Yellow River) and the Changjiang (Yangtze River) estuarine systems, Contin. Shelf Res., 10, 369-384, 1990.

Zhou, H., Li, T., Jia, G., Zhu, Z., Chi, B., Cao, Q., Sun, R., and Peng, P. a.: Sea surface temperature reconstruction for the middle Okinawa Trough during the last glacial-interglacial cycle using C37 unsaturated alkenones, Palaeogeogr. Palaeoclim. Palaeoecol., 246, 440-453, 2007. 